\title{
On the occurrence and ecological features of deep chlorophyll maxima (DCM) in Spanish stratified lakes
}

\author{
Antonio Camacho
}

Instituto Cavanilles de Biodiversidad y Biología Evolutiva y Departamento de Microbiología y Ecología, Edificio de Investigación "Jeroni Muñoz", Campus de Burjassot, Universitat de València. E-46100 Burjassot (Valencia), España. e-mail: antonio.camacho@uv.es

\begin{abstract}
Deep chlorophyll maxima (DCM) are absolute maxima of Chlorophyll- $a$ concentration among the vertical profile that can be found in deep layers of stratified lakes. In this manuscript I review the principal mechanisms that have been argued to explain the formation of DCM, which include, among others, in situ growth of metalimnetic phototrophs, differential impact of grazing between the different lake strata, and passive sedimentation to the layers where water density and cell density are equalized. The occurrence of DCM in Spanish lakes, as well as the main ecology characteristics of the oxygenic phototrophs that form DCM in these lakes is also reported. Cyanobacteria, either filamentous or unicellular, and cryptophytes, are the main components of most DCM found in the reported Spanish lakes, although diatoms, chrysophytes, dinoflagellates, and chlorophytes also contribute to these chlorophyll maxima. These organisms cope with strong physical and chemical gradients, among which those of water density, light and inorganic nutrient availability, and sulphide concentrations appear to be the most determinant factors influencing planktonic community structure.
\end{abstract}

Keywords: Deep chlorophyll maxima, Spanish lakes, stratification, cryptophytes, cyanobacteria, vertical gradients.

\section{RESUMEN}

Los máximos profundos de clorofila (DCM) son máximos absolutos de concentración de clorofila-a que pueden encontrarse en capas profundas de los lagos estratificados. En este manuscrito se revisan los principales mecanismos que se han propuesto para explicar la formación de los DCM, entre los que se cuentan, al margen de otros secundarios, el crecimiento in situ de los microorganismos fotótrofos metalimnéticos, el impacto diferencial del herbivorismo en diferentes estratos del lago, y la sedimentación pasiva hasta las capas en las que se iguala la densidad del agua con la densidad celular. También se revisa la existencia de DCM descritos en lagos españoles, así como las principales características ecológicas de los microorganismos fotótrofos oxigénicos que los forman. Tanto las cianobacterias, sean filamentosas o unicelulares, como las criptófitas, son los principales componentes de los DCM encontrados en los lagos españoles, aunque también contribuyen a ellos otras algas como las diatomeas, crisófitas, dinoflagelados y clorófitas planctónicas. Estos microorganismos se enfrentan a acusados gradientes físico-químicos, entre los cuales la densidad del agua, la disponibilidad de luz y de nutrientes inorgánicos, y la concentración de sulfhídrico, aparecen como los factores más determinantes para la estructuración de la comunidad planctónica.

Palabras clave: Máximos profundos de clorofila, lagos españoles, estratificación, criptófitas, cianobacterias, gradientes verticales.

\section{WHAT IS A "DEEP CHLOROPHYLL MAXIMUM" (DCM)?}

During the lakes' stratification period, planktonic primary producers, such as some eukaryotic algae and cyanobacteria, can achieve abundance maxima at considerable depths, especially in oligotrophic and mesotrophic lakes (Fee, 1976; Moll and Stoermer, 1982; Margalef, 1983). However, during the mixing period these maxima would not occur because turbulence mixes water preventing the accumulation of phototrophs at certain depths (Reynolds, 1994), as it happens when fall mixing occurs promoting the disappearance of these populations (Abbott et al., 1984). Reynolds (1992) reviewed the key factors that govern the onset, maintenance, and dissipation of vertical structure of the water column and the responses of phytoplankton to this structu- 
ral development, where some species forming deep populations were identified from a functional point of view as "stratifying algae" or typical from the metalimnia (Reynolds, 1997; Reynolds et al., 2002). Oligotrophic and mesotrophic conditions associated to vertical stratification and promoting epilimnetic nutrient depletion allow enough light to penetrate to the metalimnion and upper hypolimnion (Reynolds, 1992), where nutrient availability is often higher. There, this higher nutrient pool, and a sufficient light availability (or the capacity for selective harvesting), would favour growth of certain algae (St. Amand \& Carpenter, 1993). Moreover, long-lasting stratification maintain relatively constant conditions in the metalimnion and hypolimnion of lakes, from which the organisms that are adapted to cope with these conditions can take advantage, being able to colonise an environment which is quite hostile for possible competitors. As a consequence, these microorganisms can accumulate dense populations at depths where these environmental conditions overlap with their capacities, while the same conditions inhibit growth of other microorganisms. In some lakes, these phototrophs can account for an important part of the net primary production (Moll and Stoermer, 1982, Camacho et al., 2001a) and/or planktonic algal biomass (Fee, 1976; Gasol et al., 1992) within the lake.

Maximal abundances of diatoms (e.g. Fahnenstiel \& Glime, 1983; Jackson, et al., 1990; Stoermer et al., 1996; Camacho et al., 2001a; Barbiero \& Tuchman, 2001, 2004; Wolin \& Stoermer, 2005), cryptophytes (Kettle et al., 1987; Rott, 1988; Carrick \& Fahnenstiel, 1989; Arvola et al., 1991; Jones, 1991; Gervais, 1997a; Camacho et al., 2001a), cyanobacteria (Craig, 1987; Konopka 1989; Lindholm, 1992; Konopka et al., 1993; Callieri \& Pinolini, 1995; Padisák et al., 1998; Kasprzak et al., 2000; Gervais et al., 2003), as well as other algae (Vincent et al., 1980; Pick, 1984; Lindholm, 1992; Nygaard, 1996; Gerloff-Elias et al., 2005; Zvikas, 2005), forming deep chlorophyll layers have been reported mostly for temperate lakes of North America, Central and Northern
Europe, and, as it will be reviewed later, for Spain. Strictly, a "deep chlorophyll maximum" (DCM) can be referred to as the maximal chlorophyll- $a$ concentration that is found at a certain depth, usually at the thermocline or close to the upper part of the hypolimnion, far from the surface. However, this chlorophyll peak does not always represent the absolute maximum of Chl- $a$ concentration within the vertical profile, and sometimes it does not form a very sharp peak within a narrow depth interval. Then, the term "deep chlorophyll layer" (DCL) seems more appropriate (Pilati \& Wurstbaugh, 2003). In any case, the possible mechanisms for the formation and/or maintenance of both DCM and DCL seem to be the same, and some of these mechanisms can be complementary in explaining the formation of a particular DCM. Typically, a DCM is formed by only one or a few algal (or cyanobacterial) species, whose population densities are extremely high compared to epilimnetic algal abundance (Gasol et al., 1992; Miracle et al., 1992). Concerning the environmental features, the bottom part of the metalimnion and the upper hypolimnion of stratified lakes commonly present strong physical and chemical gradients of light, oxygen, sulphide, and inorganic nutrients (e.g. Fig. 1), among others, which are mediated by biological processes (Reynolds, 1992). Consequently the capacity of planktonic primary producers to establish DCM is often associated with their ability to cope with these gradients at these depths, and this results in a sharp stratification of phototrophic microorganisms (Camacho \& Vicente, 1998; Gervais, 2001; Gervais et al., 2003). Lake morphometry and wind exposure, which can strongly influence the mixing pattern (Margalef, 1983; Wetzel, 2001), would also be important features for the formation of DCM. Since these metalimnetic layers have been often described as environments with low predation, which allows biomass accumulation (Pedrós-Alió et al., 1987; Gasol et al., 1992; Massana et al., 1996), long-lasting stratification can additionally help the success of metalimnetic phototrophs when outcompeting other species (Naselli-Flores et al., 2003). 


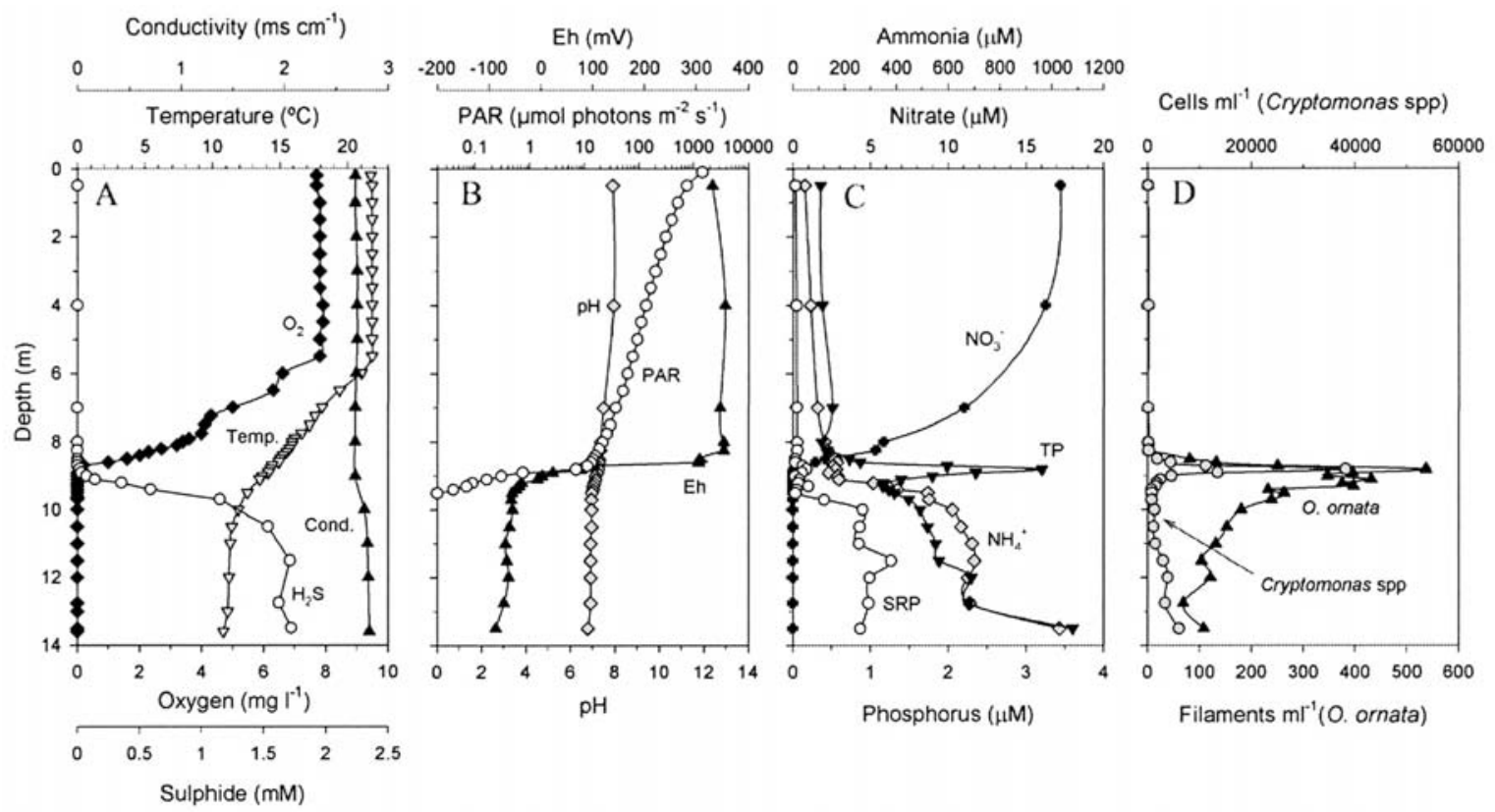

Figure 1. Typical limnological features and vertical distribution of DCM-forming oxygenic phototrophs in Lake Arcas in September, during the period of stronger stratification. Características limnológicas típicas y distribución vertical de los microorganismos fotótrofos oxigénicos que forman un DCM en la Laguna de Arcas, en septiembre, cuando se da la máxima estratificación.

\section{POSSIBLE MECHANISMS OF DCM FORMATION}

Whatever the mechanism responsible for the formation of the DCM, the stability of the water column appears as the main factor related to the formation of DCM, since this stability allows for the development of strong gradients in chemical conditions and water density, which, regardless the mechanism, strongly determine phytoplankton distribution through the vertical profile. It seems clear that a DCM is not found in lakes where a pycnocline is too deep or absent (Abbott, 1984). For example, physical parameters of stability (S) were calculated for several lakes (Camacho et al., 2003a, 2003b; Chicote, 2004) and were strongly correlated to the metalimnetic concentration of chlorophyll associated with the formation of DCM by typically metalimnetic phototrophs such as certain species of cryptophytes and cyanobacteria.

One of the mechanisms proposed to explain the formation of DCM is in situ growth of phototrophs (Fahnenstiel \& Glime, 1983; Gasol et al., 1992; Miracle et al., 1992), favoured by the high- er nutrient availability at the bottom part of the metalimnion and upper hypolimnion. In situ growth of phototrophs in deep layers is theoretically possible when the euphotic depth is higher than the mixing depth (Thornton et al., 1990). During stratification, nutrient depletion occurs in the epilimnion of oligotrophic and mesotrophic lakes (Margalef, 1983; Christensen et al., 1995). Contrastingly, deep layers at the bottom part of the thermocline are much richer in inorganic nutrients (Margalef, 1983) due to the settling and recycling of particulate material from upper layers, as well as by resolubilization of inorganic nutrients from the sediments, since some substances, such as some phosphorus compounds, have higher solubility in the slightly acidic and reduced waters of the anoxic hypolimnia than do at the oxygen-rich layers of the epilimnia. In fact, it has been reported that metalimnetic seston showed lower C: P ratios than that of the epilimnion (Barbiero \& Tuchman, 2001), which can be interpreted as an evidence of improved nutritional conditions in deep layers. Epilimnetic nutrient depletion, when prolonged, prevents massive algal growth in shallower waters, thus 
increasing light availability in deeper waters, which is dominated by certain wavelengths that are not selectively absorbed in upper waters anyway. Primary producers, if they are phototrophs, need not only inorganic nutrients for growth, but also light. Consequently, a compromise between being so deep to be able to get higher nutrient availability, but shallow enough to be able to harvest enough light for photosynthesis, seems necessary for algal growth in deep layers. The latter, the question of getting enough light, would be partly solved if phototrophs had accessory

Lake Arcas 20 September 1996

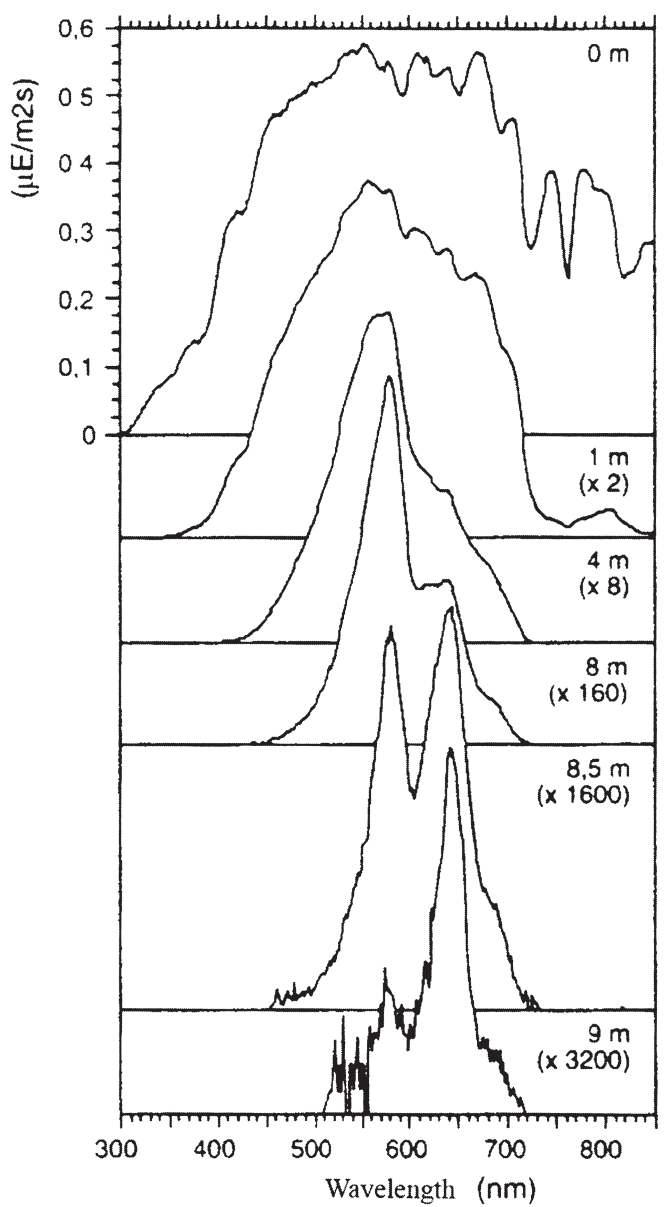

Figure 2. Light availability at different depths of Lake Arcas in September measured with a spectroradiometer, during the period of stronger stratification. Figure design and measures performed by X. Vila (UdG). Disponibilidad de luz en diferentes profundidades de la Laguna de Arcas medida con un espectroradiometro durante el periodo de máxima estratificación. Medidas y diseño de la figura realizados por X. Vila (UdG). pigments allowing them to capture the wavelengths available at these depths. Because of the selective extinction in upper layers, either by water, by the photosynthetic pigments of overlying algae, or by other dissolved and particulate materials, light arriving to deep layers of lakes mainly corresponds to the central part of the PAR spectrum (Fig. 2), this is, from 550 to $630 \mathrm{~nm}$ (Gervais, 1991; Callieri et al., 1996; Vila et al., 1996; Camacho, 1997), those wavelengths that may selectively be harvested by phycobiliproteins such as phycoerythrin or phycoerythrocyanin (Rowan, 1989, Gervais, 1997a; Wetzel, 2001). Consequently, algae and cyanobacteria presenting these phycobilins have a selective advantage to cope with the low light availability at the metalimnion, where nutrient limitation can be less severe, then being able of in situ growth forming DCM. The capacity for vertical movement, either active by flagella, or by buoyancy mechanisms, is also a feature of most planktonic primary producers that are able to grow in deep lake layers, since the capacity of movement allows them to move across the strong physical and chemical gradients found at the bottom part of the metalimnion to get their optimal position for balanced growth. In situ growth seems to well explain the formation of DCM by cryptophytes or cyanobacteria, which are rich in phycoerythrin when forming DCL (Stockner et al., 2000; Camacho et al., 2001b; Camacho et al., 2003a), and this usually results in increased photosynthetic efficiencies (Callieri \& Piscia, 2002).

Differential predation pressure between top and deep lake layers has been also argued as a possible mechanism favouring the formation and maintenance of DCM (e.g. Pedrós-Alió et al., 1987; Pilati \& Wurtsbaugh, 2003). According to this mechanism, regardless of the growth rates shown by algae at shallow or deep layers, if grazing pressure is much lower in the metalimnion (Gasol et al., 1992, 1993; Jones, 1993; Massana et al., 1996) than in the epilimnion, population increase of epilimnetic algae can be restricted by grazing, whereas a lower grazing pressure at the metalimnion would allow algal accumulation at these depths, which will then form the DCM in a process favoured by increased light availability 
because of stronger phytoplankton removal in the upper layers (Christensen et al., 1995). Pilati \& Wurtsbaugh (2003) found that this mechanism could be partly responsible for the formation of the DCM in an ultraoligotrophic lake in the mountains of Idaho (USA), but in this case algal abundances were very low even at the metalimnion (Chl- $a$ usually lower than $1.5 \mathrm{mg} \mathrm{m}^{-3}$ ). Certainly, this mechanism can partly promote the formation of DCM by differentially removing more algal biomass from the epilimnion. However, it does not seem sufficient by itself to explain its formation in lakes where the DCM is composed by much more dense populations of phototrophs, at least in mesotrophic deep lakes where epilimnetic nutrient exhaustion would occur during the stratification period. In fact, zooplankton (crustaceans, rotifers and/or protozoa) can be very abundant at depths where the DCM develops (e. g. Adrian \& Schipolowski, 2001). Moreover it is well known that zooplankton can perform diel vertical migrations (e.g. for Spanish lakes in Gasol et al., 1995; King \& Miracle, 1995; Boronat \& Miracle, 1997; Armengol \& Miracle, 2000), and might play a crucial role in the vertical nutrient transport within the lake (Vanni, 2002). Some crustacean species that are common in stratified lakes can spend part of the day at the metalimnion (Lampert \& Grey, 2003). There, they are able to efficiently graze on the metalimnetic populations of planktonic primary producers (Christensen et al., 1995; Williamson et al., 1996; Adrian et al., 2001; Camacho et al., 2001a), although they must face a trade-off related to the higher temperatures in the epilimnion opposed to the higher food availability in the meta- and hypolimnion (Lampert \& Grey, 2003, Kessler \& Lampert, 2004). There is clear evidence that food resources for zooplankton in deep-water layers can be as profitable as those from upper layers (Winder et al., 2003), while these resources are much more abundant at the DCM. Although it has been reported that the quality of these food resources could be lower at the DCM (Cole et al., 2002), most studies did not find this lower quality (Winder et al., 2003). In fact, algae such as Cryptomonas, which are common in DCM, are generally considered as a high quality food (Barone \& Naselli-Flores, 2003). In Spanish lakes, the best documented case of crustacean predation on metalimnetic algae is that of Daphnia pulex grazing on Cryptomonas in Lake Cisó, which caused a strong impact on these photoautotrophs in microaerobic layers of the lake where the DCM was located (Massana et al., 1994, 1996). Additionally to crustaceans, ciliated protozoa are also abundant in the microaerobic and anoxic waters of some of the Spanish lakes later referred to in this manuscript (Fenchel and Finlay, 1991; Finlay et al., 1991; Esteban et al., 1993; Massana \& Pedrós-Alió, 1994; Massana et al., 1994). Among these, in Lakes Arcas and Cisó, it has been demonstrated that ciliates can consume Cryptomonas from the DCM although its consumption on their populations seems much lower than the standing crop of these algae (Finlay et al., 1991; Guerrero \& Pedrós-Alió, 1992; Pedrós-Alió et al., 1995; Massana et al., 1996). Direct feeding on phototrophs is not the only trophic benefit that protozoans can obtain by living in these layers. Maximal bacterial activities and growth have often been recorded associated to the DCM fuelled by phytoplankton excretion (Auer \& Powell, 2004), and bacteria are in turn a suitable food source for protozoans. On the other hand, rotifers have also been described to peak at the chemocline of some Spanish karstic lakes mentioned in this revision, such as those from Cuenca (Miracle \& Vicente, 1983; Esparcia et al., 1991; Armengol-Díaz et al., 1993; Miracle \& Armengol-Díaz 1995; Armengol et al., 1998), with species such as Filinia hofmanii (Miracle et al., 1992) or Anuraeopsis miraclei (Koste, 1991) almost been restricted to the oxycline. However, its possible grazing impact on metalimnetic phototrophs in these lakes is not yet well known. Massana \& Pedrós-Alió (1994), on the other hand, demonstrated that rotifers from the genus Polyarthra, which together with other rotifers were found in the microaerobic layers of Lake Cisó (Alfonso \& Miracle, 1987), efficiently feed on the metalimnetic Cryptomonas populations of this lake. Nevertheless, despite these algae serve as food for several phagotrophic species, overall grazing impact on Cryptomonas was relatively low. In addition to the lower grazing 
losses, low respiration (maintenance) rates would also allow for the appearance of a DCM if the growth of phototrophs overcompensates these losses. Consequently, the lower population losses at the metalimnion should be considered in fact as an additional mechanism improving the already described formation of the DCM by in situ growth of phototrophs. This is especially true when anoxic waters contain sulphide, thus diffi- culting predation by metazoan zooplankton, which does not commonly penetrate sulphiderich layers (Miracle \& Alfonso, 1993; Massana et al., 1996; Lass et al., 2000). Actually, the highest Chl- $a$ concentrations recorded at the DCM in Spanish lakes that we report correspond to lakes exhibiting relatively high sulphide concentrations in the vicinity of the DCM, such as lakes Arcas and Cisó (Table 1).

Table 1. Deep chlorophyll maxima (DCM) reported from Spanish lakes. PE-APP = Phycoerythrin-containing unicellular picocyanobacteria, n.a. = data not available. Máximos profundos de clorofila (DCM) que se han publicado en lagos españoles. PE-APP=picocianobacterias unicelulares con ficoeritrina, n.a. = datos no disponibles.

\begin{tabular}{|c|c|c|c|c|c|c|}
\hline Lake & $\begin{array}{l}\text { Location } \\
\text { (Province) }\end{array}$ & $\begin{array}{l}\text { Type } \\
\text { of lake }\end{array}$ & Phytoplankton forming DCM & $\begin{array}{l}\text { Depth } \\
\text { (m) }\end{array}$ & $\begin{array}{l}\text { Maximum } \\
{[\mathrm{Chl-a}]_{\mathrm{DCM}}} \\
\left(\mathrm{mg} \mathrm{m}^{-3}\right)\end{array}$ & Reference \\
\hline Arcas & Cuenca & Karstic & $\begin{array}{l}\text { Oscillatoria (Planktothrix) } \\
\text { Cryptomonas spp. }\end{array}$ & $8-9$ & 298 & $\begin{array}{l}\text { Camacho, } 1997 \\
\text { Camacho et al., 2000a } \\
\text { Camacho et al., 2001b }\end{array}$ \\
\hline Arreo & Álava & Karstic & $\begin{array}{l}\text { Cryptomonas spp. } \\
\text { Cyclotella, Monoraphidium } \\
\text { Pseudokephyrion }\end{array}$ & $\begin{array}{l}6-7 \\
3-5\end{array}$ & n.a. & $\begin{array}{l}\text { Chicote, } 2004 \\
\text { Chicote et al., in prep. }\end{array}$ \\
\hline Atazar & Madrid & Reservoir & $\begin{array}{l}\text { Planktothrix } \\
\text { rubescens }\end{array}$ & $0-10$ & 22 & Almodovar et al., 2004 \\
\hline Banyoles & Girona & Karstic & $\begin{array}{l}\text { Cyclotella spp. } \\
\text { Cryptomonas spp. }\end{array}$ & $\begin{array}{c}5 \\
13-14\end{array}$ & $\begin{array}{l}3.6 \\
20\end{array}$ & $\begin{array}{l}\text { Planas, 1973, } 1990 \\
\text { García-Gil et al., } 1993\end{array}$ \\
\hline Cisó & Girona & Karstic & $\begin{array}{l}\text { Cryptomonas } \\
\text { phaseolus } \\
\text { Endosymbiotic Chlorella }\end{array}$ & $1-1.5$ & 850 & $\begin{array}{l}\text { Pedrós-Alió et al., } 1987 \\
\text { Gasol et al. } 1992 \\
\text { Massana \& Pedrós-Alió, } 1994 \\
\text { Pedrós- Alió et al., } 1995\end{array}$ \\
\hline Gorg Blau & Mallorca & Reservoir & $\begin{array}{l}\text { Oscillatoria } \\
\text { rubescens }\end{array}$ & $16-18$ & n.a. & $\begin{array}{l}\text { Ramón \& Moyà, } 1984 \\
\text { Moyà et al., } 1993\end{array}$ \\
\hline La Concepción & Málaga & Reservoir & Ceratium hirundinella & $8-10$ & 58 & Gálvez et al., 1988 \\
\hline El Tobar & Cuenca & Karstic & $\begin{array}{l}\text { PE-APP Chlamydomonas } \\
\text { Gloeocapsa }\end{array}$ & $11-12$ & 90 & $\begin{array}{l}\text { Miracle et al., } 1993 \\
\text { Vicente } \text { et al., } 1993 \\
\text { García-Gil et al. } 1999 \\
\text { Camacho et al., } 2002\end{array}$ \\
\hline Estanya & Huesca & Karstic & $\begin{array}{l}\text { Oscillatoria } \\
\text { C. phaseolus } \\
\text { Euglena acus }\end{array}$ & $15-20$ & $>10$ & Ávila et al., 1984 \\
\hline Forata & Valencia & Reservoir & Planktothrix & 8 & 15 & Dasí et al., 1998 \\
\hline Laguna del Tejo & Cuenca & Karstic & $\begin{array}{l}\text { PE-APP, Cryptomonas spp. } \\
\text { Chlorophytes }\end{array}$ & 19 & 12 & $\begin{array}{l}\text { Camacho et al., 2003c } \\
\text { Morata et al., } 2003\end{array}$ \\
\hline La Cruz & Cuenca & Karstic & PE-APP, Cryptomonas spp. & $10-12$ & 25 & $\begin{array}{l}\text { Rojo \& Miracle, } 1987 \\
\text { Dasí \& Miracle, } 1991 \\
\text { Camacho et al., 2003b }\end{array}$ \\
\hline Lagunillo del Tejo & Cuenca & Karstic & $\begin{array}{l}\text { Oscillatoria, } \\
\text { Cryptomonas spp. } \\
\text { Endosymbiotic Chlorella }\end{array}$ & $4-11$ & 15 & $\begin{array}{l}\text { Vicente \& Miracle, } 1984 \\
\text { Camacho et al., 2003a }\end{array}$ \\
\hline La Parra & Cuenca & Karstic & $\begin{array}{l}\text { PE-APP } \\
\text { Cryptomonas spp. }\end{array}$ & 9 & 15 & Camacho et al., 2003a \\
\hline Montcortes & LLeida & Karstic & Oscillatoria & n.a & n.a. & Camps et al., 1976 \\
\hline Redo & LLeida & Alpine & $\begin{array}{l}\text { Chrysophytes } \\
\text { Cryptophyes }\end{array}$ & $28-45$ & 2.3 & $\begin{array}{l}\text { Felip et al., } 1999 \\
\text { Felip \& Catalán, } 2000 \\
\text { Ventura et al., } 2001\end{array}$ \\
\hline
\end{tabular}


Passive (or active e.g. Pick et al., 1984; Gálvez et al., 1988) depth-differential sinking of epilimnetic algae is the third main mechanism proposed to explain the formation of DCM (Cullen, 1982; Jackson et al., 1990). According to this mechanism, algae that would form a DCL grow at the epilimnion where light availability is high. Due to sedimentation, algae tend to progressively accumulate at a depth where cell density equals water density (neutral buoyancy), or, at least, where water density increases. This, accompanied by the decrease in sinking rates associated to higher nutrient availability (Davey \& Heaney, 1989; Jackson et al., 1990; Wetzel, 2001), promotes slower sinking. In a stratified lake, water density increases with depth at the thermocline. If cell density is close to that of water, cell settling will stop when cell and water densities balance, and algae will remain at these layers until changes in water density, usually associated to vertical mixing, occur. Consequently, with this mechanism algae can accumulate at the thermocline, which creates the density gradient, along summer. If stratification remains, nutrient depletion can occur in the epilimnion, growth of epilimnetic algae is then restricted as stratification advances, and consequently the DCM formed by settling algae becomes more evident until mixing occurs. This has been the main mechanism mostly argued to explain the formation of DCM by non-motile phytoplankters, such as diatoms. Since these algae lack active buoyancy regulation and other mechanisms for active movement, they cannot actively regulate their position in the water column. As a consequence, they tend to accumulate at a depth in which their cell density equals water density. Wetzel (2001) reviewed sinking rates of diatoms from data of different authors. He showed that cell settling was certainly dependent on several factors, such as the growth phase of the population or nutrient availability. He found sinking rates ranging from 0.1 to $2 \mathrm{~m} \mathrm{day}^{-1}$ for most diatoms, although this of course, would also depend on the turbulence in the lake and the nutritional status of the cells. However, this kind of diatom-dominated DCM are poorly know since neither cell density, the capacity for remaining active at these depths, or losses by other several factors, have been extensively studied so far. It is assumed that these DCM are fed only by algae settling from the epilimnion, where growth mostly occurs, and losses can be explained both by predation and by decomposition, although these concerns have not yet been conclusively demonstrated. For instance, Fahnenstiel \& Glime, (1983) reported that the DCM found at the metalimnion of Lake Superior, which was dominated in their upper layer by Cyclotella spp. and in the lower portions by flagellated algae, was nevertheless generated by in situ production. Similarly, in a much smaller waterbody such as Lake Cadagno, Camacho et al. (2001a) found that the upper part of the DCM, mostly formed by diatoms, was also photosynthetically active. Nevertheless, in this lake, the specific carbon fixation per Chl- $a$ unit per available photon at the depth occupied by diatoms was lower than those of the cryptophyte-dominated lower part of the DCM, whose maximum abundance coincided with maximal rates of oxygenic photosynthesis. These two examples show how it is not always clear that diatom-formed DCM are only explained by sedimentation, and further work is necessary to clarify it. In addition to the already described mechanism of progressive accumulation of algae settling at the metalimnion, quick blooming and sinking, followed by progressive degradation of settled algae has also been described as a slightly different mechanism by which algal (chrysophytes in this case) sedimentation could originate a DCM (Pick et al., 1984).

A fourth mechanism, not often cited, for the formation of DCM can be the symbiotic association of algae with protozoa, followed by blooming at the metalimnion. For instance, Queimaliños et al. (1999) and Modenutti et al. (2004, 2005) described the formation of a DCM by symbiotic green algae from the genus Chlorella in association with ciliated protozoa in Andean lakes. Usually, in symbiotic interactions between heterotrophic protists and algae, the latter provides products for the photo- 
synthesis, whereas the heterotrophic protist can provide inorganic nutrients and movement. Ciliated protozoa are often very abundant at the oxic-anoxic interface of stratified lakes (Finlay et al., 1991; Esteban et al., 1993; Massana \& Pedrós-Alió, 1994), and it is relatively common for these ciliates to present endosymbiotic algae (Esteve et al., 1988; Finlay et al., 1991). Consequently, the high abundance of ciliates at these depths, with many of them presenting several algal symbionts per cell, could also contribute to the formation of a DCM close to the oxic-anoxic boundary.

Cullen (1982) and other authors also hypothesised about a fifth mechanism of DCM formation consisting in the photo-acclimation of the phytoplankton living in deep layers by which these phototrophs would increase the chlorophyll content per cell (Berner et al., 1989; Falkowski \& Raven, 1997), resulting in elevated Chl- $a$ concentrations in deep waters without significant increase in biomass. Fennel $\&$ Boss (2003) have modelled this effect and predicted that biomass and chlorophyll maxima would be vertically separated because the former would be generated by balanced growth and losses, and the latter by photoacclimation. This vertical segregation of phytoplankton biomass and chlorophyll maxima has also been reported for other lakes (e.g. Felip \& Catalán, 2000), which were quite transparent as well. This question though, is still more complicated, since it has been reported that an increase in phytoplankton biomass can also be due to an increase in the average dimensions of organisms instead of an increased cell number (Rojo \& Álvarez-Cobelas, 2003). Although photo-acclimation could be relevant to explain DCM formation in some lakes with very high water transparency, it should be taken into account that the wavelengths reaching deep layers in non-ultraoligotrophic lakes are usually biased to a part of the spectrum that is not easily harvested by chlorophyll. In such lakes, blue and red bands have been selectively extinguished in overlying waters either by the absorption of epilimnetic phytoplankton, water, or dissolved substances. Instead, metalimnetic phototrophs from mesotrophic lakes might increase the specific content of phycoerythrin per cell as the depth increases (Gervais et al., 1997a; Camacho et al., 2003a, 2003b). This would allow them to more efficiently capture light at deep layers, so that the strategy of increasing chlorophyll content would not be significant in these cases.

Although it has been cited elsewhere (e.g. Karentz et al., 1994; Neale et al., 2001; Modenutti et al., 2005) it is not likely that photo-inhibition in the upper layers would generally be a determining factor for the formation of DCM. A possible exception are, perhaps, extremely clear lakes, in which a great portion of the epilimnion could be under the influence of high irradiation including high UV exposure, such as many alpine lakes (Sommaruga, 2001; Modenutti et al., 2004). However, photo-inhibition of phytoplankton growth is thought to occur for most lakes only in the upper layers during just a few hours a day. Consequently, this would not explain by itself the substantially lower algal growth through the whole epilimnion in all kind of lakes.

As a conclusion for this part, it can be considered that all the above reported mechanisms are likely to contribute, with higher or lower importance, to the formation of DCM in different types of lakes. The special features of each lake (nutrient status, morphometry and mixing patterns, etc) would determine to what extent one of these mechanisms is mainly responsible for the appearance and further maintenance of a DCM in a particular lake. A good example is found in Sawatzsky et al., (2006), who performed an experimental study in which they considered the influence of both nutrient avalability and grazing impacts on DCL formation in ultraoligotrophic mountain lakes. They demonstrated the interplayed relevance of nutrient limitation (and inhibition) and the effects of grazing mortality and nutrient recycling on phytoplankton communities forming DCM. Their results indicate that, although severe epilimnetic nutrient limitation was at the basis of the DCM formation, spatial and temporal differences in grazing by zooplankton played an important role in the appearance and maintenance of the DCM. These 

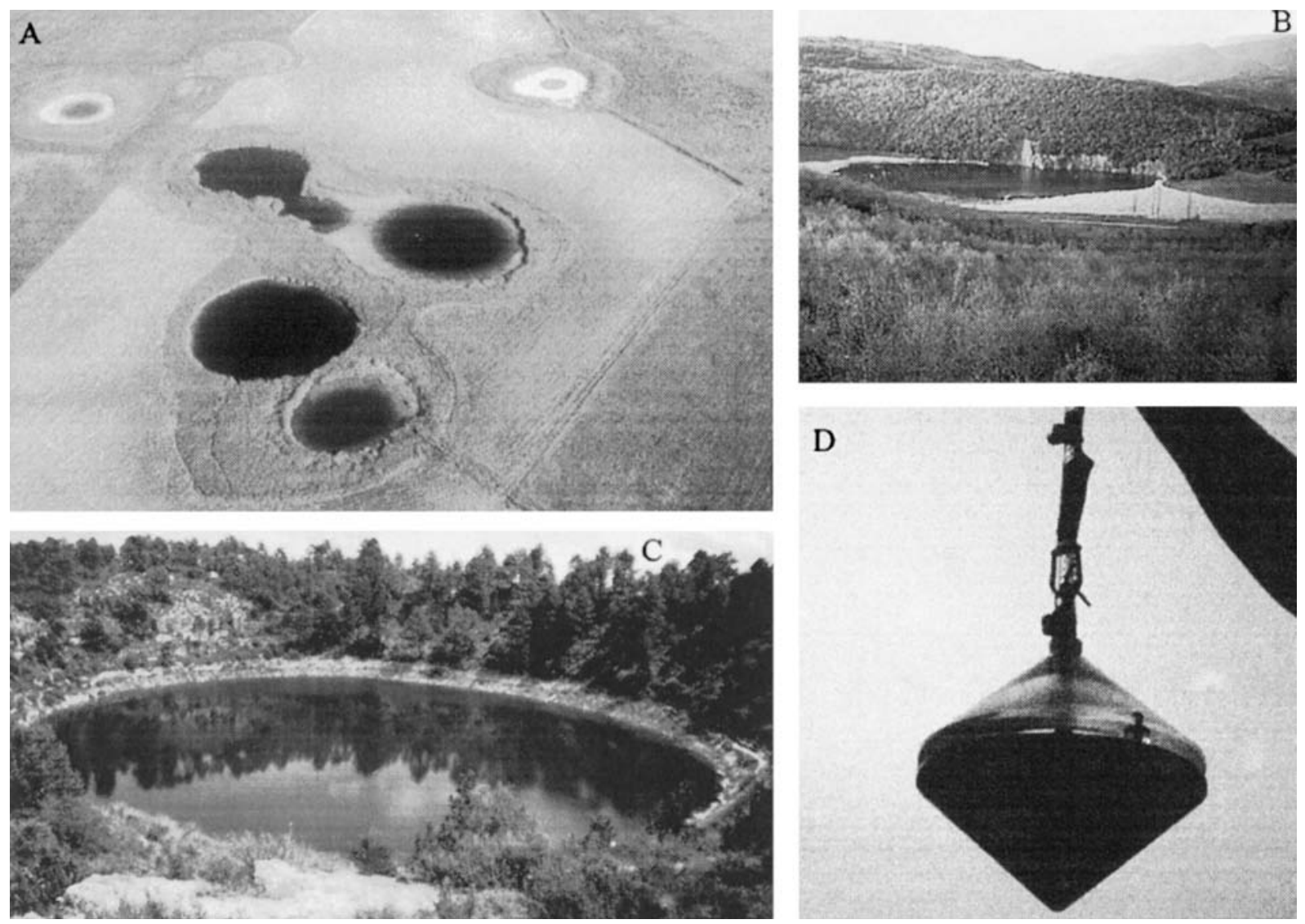

Figure 3. (A) Aerial view of Lake Arcas and other dolines in its vicinity (photograph by E. Vicente); (B) Lake Arreo (photograph by A. Chicote); (C) Lake La Cruz (photograph by L. Romero); and (D) Double cone sampler used for careful vertical sampling. (A)Vista aérea de la Laguna de Arcas y otras dolinas próximas (fotografía de E. Vicente); (B) Lago de Arreo (fotografia de A. Chicote); (C) Laguna de la Cruz (fotografía de L. Romero); y (D) muestrador de doble cono para realizar muestreos verticales finos.

authors hypothesized that the formation of the DCM in the studied lakes could be attributed initially to higher zooplankton grazing. This would exhaust epilimnetic phytoplankton populations, which then were not capable of further growth because of summer nutrient depletion (and cannot provide enough food for maintaining zooplankton). This would in turn increase transparency that would benefit metalimnetic plankton. In fact, similar combined mechanisms for DCM formation and maintenance can explain DCM in many of the reported Spanish lakes as explained below. Indeed, in situ growing of metalimnetic algae experiencing lower grazing pressure than epilimnetic algae enhances in turn the sharpness of the metalimnetic Chl- $a$ maxima, thus forming the DCM.

\section{HOW TO SAMPLE DCM}

Common sampling techniques are usually not valid for sampling DCM. Firstly, the abundance of the phototrophic microorganisms forming DCM can change by several orders of magnitude in just a few centimetres within the vertical profile. Secondly environmental variables can also vary within the same depth range due to the strong physical and chemical gradients established at these depths when stratification occurs. In vertically heterogeneous deep lakes extreme care should be taken with sampling methodology to readily get the real structure of phytoplankton populations (Naselli-Flores et al., 2003). García-Gil \& Camacho (2001) gave specific recommenda- 
tions for correct sampling in these strongly stratified systems. For instance, classical hydrographic bottles, which extend for many centimetres, are unsuitable for determining these spatial changes. Consequently, fine and detailed vertical sampling must be resolved using samplers allowing enough vertical resolution to describe the vertical structure of the photosynthetic populations.

Jørgensen et al., (1979) described a double cone mechanism, in which plastic cones are joined at their bases with a space of $1 \mathrm{~cm}$ between them (Fig. 3D). These cones are ballasted and connected with a waterspout to a pump which sucks water from the desired depth with a vertical resolution of about 2.5-5 cm (Børsheim et al., 1985). Børsheim et al., (1985) also designed a multi-syringe pneumatic mechanism, which is suitable for obtaining samples every 3 $\mathrm{cm}$, but compared to the double cone it has the disadvantage of getting much less water volume per depth, although a much higher number of samples (up to 33 per meter in the Børsheim model) can be obtained simultaneously. Miracle et al., (1992) presented a detailed description, including figures, of these two sampling systems suitable for detailed vertical studies.

Once collected, samples should be protected from contact with the air, since these samples are usually microaerobic or anoxic, and any exposure to oxygen could promote strong chemical and biological alterations in the sample. They should also be protected from light, because these microorganisms also experience a much darker environment than those found at the lake surface.

\section{DCM IN SPANISH LAKES}

In Spain, thermal stratification occurs during summer in lakes having an adequate morphometry to allow the development of a temperature gradient through the vertical profile, and consequently these lakes are monomictic. Contrastingly, dimictic lakes in the Iberian Peninsula are restricted to high mountains where ice covers the lake during winter, thus promoting winter stratification.
Most studies describing the appearance of DCM in Spanish lakes have been performed either in karstic lakes or in artificial reservoirs, although many extensive studies on phytoplankton in Spanish deep freshwater systems have not been centred in the vertical distribution of phytoplankton (e.g. Dasí et al., 1998; Negro \& de Hoyos, 2005). Many Spanish lakes are shallow, as a result of endorheic processes forming steppic lakes (Alonso, 1998; Camacho et al., 2003a), as well as coastal shallow lakes sometimes formed on quaternary floodplains (Vicente \& Miracle, 1992). Contrastingly, deep natural lakes in Spain are often associated to karstic processes (Fig. 3), promoting the formation of dolines that are filled with water from the karstic aquifer (Miracle \& Gonzalvo, 1979; Miracle et al., 1992). The zones of the Serranía de Cuenca (Castilla - La Mancha, central-east Spain), Banyoles (Girona, Catalonia, NE Spain), and the Pre-Pyrenean mountains of Huesca and Lleida (NE Spain) are among the richer areas in karstic lakes in the Iberian Peninsula. A second type of deep lakes in Spain is the Alpine type (Catalán et al., 1992; MoralesBaquero et al., 1992; Camarero et al., 1999; Ventura et al., 2001), whereas man-made lakes (reservoirs) are the third main type of deep lakes in the Iberian Peninsula (Margalef, 1976, Riera et al., 1992). Among these three types, the thermal stratification regime can differ extensively. Karstic lakes usually have low (if any) surface runoff, and consequently a strong thermal stratification remains from late spring to early autumn (García-Gil et al., 1993; Rodrigo, 1997). Most of them are small $(<2 \mathrm{Ha})$ and present a very high relative depth, which favours the stability of the water column during the stratification period (Camacho et al., 2003a), although the bigger Lake Banyoles also has a karstic origin and stratifies during summer (Planas, 1973), showing some meromictic basins as well (Planas, 1990). The alpine lakes, however, usually develop an ice cover during winter, thus showing winter stratification and sometimes also weak summer stratification. Reservoirs can also be stratified during summer, at least in the zones where flow is relatively low. For instance, Margalef et al., (1976) reported an extensive study on Spanish reservoirs 
in which interesting data on algae dominating in deep layers are included. Among all these types of Spanish deep lakes, both karstic lakes and artificial reservoirs, this is, those showing stronger summer stratification, have been reported to present DCM, whereas reports of DCM in Spanish alpine lakes are much less common (Felip et al., 1999; Felip \& Catalan, 2000).

The main phototrophic microorganisms that have been described forming DCM in Spanish lakes are, like in similar lakes around the world (Reynolds, 1992, Adler et al., 2000), cryptophytes and cyanobacteria (Table 1, Fig. 4). These phototrophs can accomplish the two main requi- rements to be able of in situ growth in deep layers, this is, the capacity of synthesise phycoerythrin for light harvesting (Gervais, 1997a; Camacho et al., 2000a, 2001b), and the ability to regulate their vertical position in the water column, either by flagellar movement (cryptophytes) or by buoyancy (filamentous cyanobacteria), which minimises sinking losses of these populations. However, the capacity of buoyancy regulation has not been described for unicellular picocyanobacteria (Stockner et al., 2000), although they are also able of producing phycoerythrin (Camacho et al., 2003a) and can also form DCM in stratified lakes. It has been hypo-
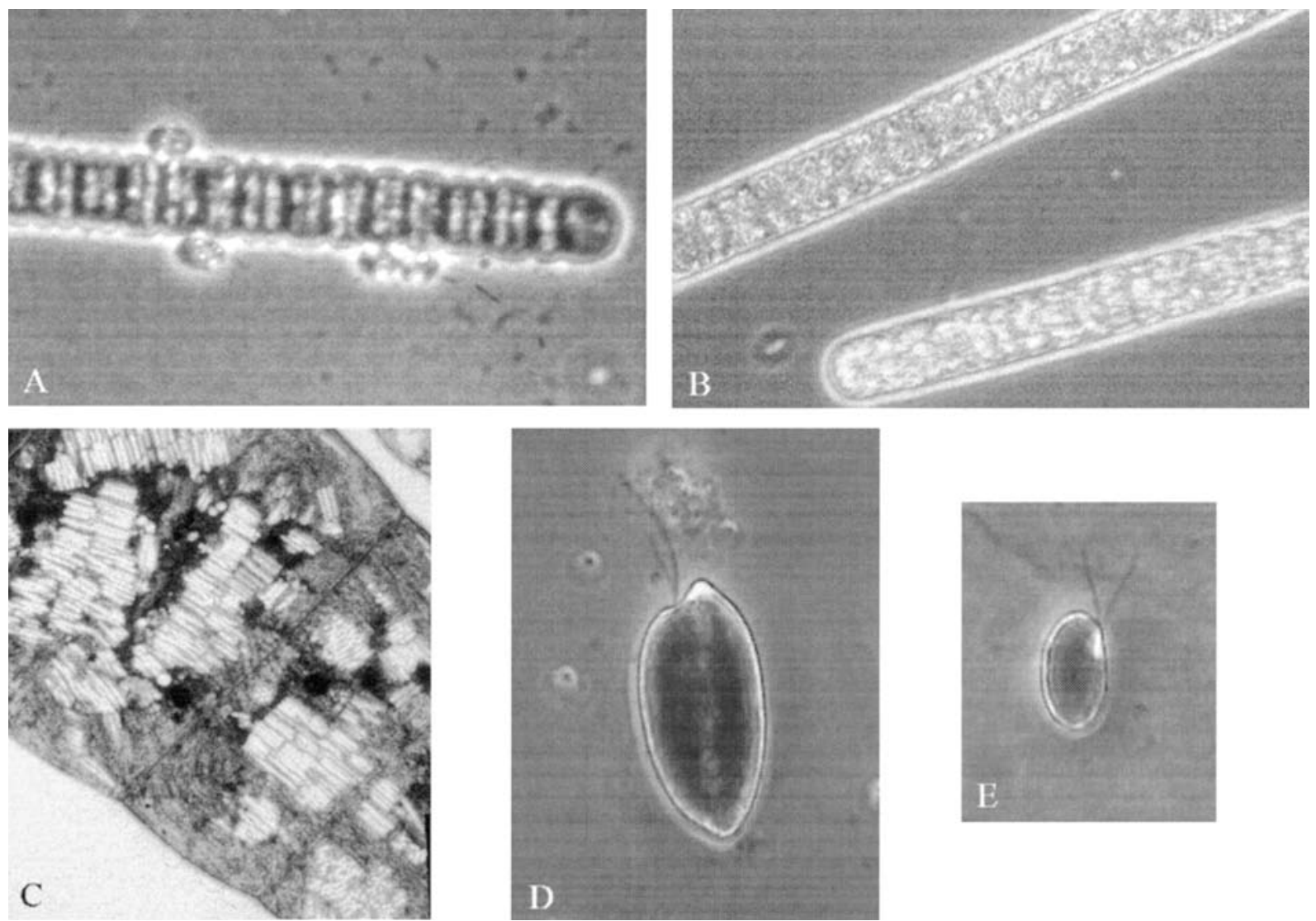

Figure 4. Main oxygenic phototrophs from the DCM of Lake Arcas. (A) Oscillatoria (= Planktothrix) without gas vesicles from the hypolimnion accompanied by purple sulphur bacteria Chromatium weisssei; (B) Oscillatoria (= Planktothrix) with gas vesicles from the upper part of the DCM; (C) Transmission electron microscopy photograph showing gas vesicles from Oscillatoria (= Planktothrix) (photograph by K. Clarke). (D) Cryptomonas erosa; and (E) Cryptomonas phaseolus. Principales microorganismos fotótrofos oxigénicos que forman el DCM en la Laguna de Arcas. (A) Oscillatoria (= Planktothrix) sin vesiculas gaseosas, en una muestra del hipolimnion en la que también aparece la bacteria fotosintética del azufre Chromatium weisssei; (B) Oscillatoria (= Planktothrix) con vesículas de gas, procedente de la parte superior del DCM; (C) Microfotografía de microscopia electrónica de transmisión que muestra las vesículas gaseosas de Oscillatoria (= Planktothrix) de la Laguna de Arcas (fotografía de K. Clarke) (D) Cryptomonas erosa; $y$ (E) Cryptomonas phaseolus. 
thesized that these unicellular picocyanobacteria can form dense populations because these microorganisms do not settle (Stockner et al., 2000), although it has been demonstrated, however, that strong population losses by sinking can occur associated to massive calcium carbonate precipitation occurring in summer (Miracle et al., 2000; Camacho et al., 2003b). Otherwise, sinking losses of picocyanobacteria are commonly very low.

Based on a cost-benefit analysis, Raven and Richardson (1984) hypothesized that vertical migration of some flagellated algae could increase their growth rate. Vertical migration by cryptophytes has been described as a mechanism enabling these algae to harvest inorganic nutrients from richer deep lake layers (Salonen et al., 1984, Arvola et al., 1992), then migrating to upper layers where light availability increases (Camacho et al., 2001b). However, it has also been remarked that increased nutrient availability was not always achieved by moving downwards (Gervais et al., 2003). The most commonly described pattern, anyway, is that cryptophytes migrate downwards in the afternoon or in the evening to spend most night at their deepest, nutrient-richer, point, then migrating upwards at dawn to situate at their shallower depth during the morning, where they can get higher light availability and escape from sulphide inhibition of photosynthesis (Arvola et al., 1991; Gasol et al., 1993; Gervais, 1997b; Camacho et al., 2001b). This is, for instance, the common migration pattern found in lakes Arcas (Rodrigo et al., 1999; Camacho et al., 2001b) and Cisó (Gasol et al., 1991, 1992), both showing a sulphide-rich anoxic hypolimnion (Gasol et al., 1992; Rodrigo et al., 2000a) where Cryptomonas spp. penetrate at night. The same pattern is also found in Lake Arreo (Chicote, 2004), a karstic lake lying on evaporites located in Álava (Rico et al., 1995; González-Mozo et al., 2000), where hypolimnetic sulphide concentrations are lower (Chicote, 2004). In these lakes the cryptophyte species contributing to the DCM are Cryptomonas erosa and C. phaseolus in Lake Arcas (Camacho et al., 2001b), reaching maximum abundance of $3.8 \times 10^{4}$ cell $\mathrm{ml}^{-1}$; C. phaseolus in Lake Cisó (maximum abundance of up to $10^{5}$ cell $\mathrm{ml}^{-1}$; Pedrós- Alió et al., 1987); and C. erosa, C. phase- olus and C. marsonii in Lake Arreo (Chicote, 2004), with maximal reported abundance of Cryptomonas spp. of $5.62 \times 10^{4}$ cell ml-1. Among these species, C. phaseolus is usually found deeper (Gasol et al., 1993; Gervais, 1997b; Camacho et al., 2001b; Chicote, 2004), whereas the other species, although commonly showing high abundance at the DCM in microaerobic or anoxic waters, are usually present at slightly shallower depths than $C$. phaseolus. At least in some of the lakes mentioned above (Camacho et al., 2001b; Chicote, 2004) these cryptophytes take advantage of the higher phosphorus availabilities at the depth where the DCM is located or below, reaching these layers by vertical movements. Migration in these lakes range from the $40 \mathrm{~cm}$ by Cryptomonas phaseolus in Lake Cisó (Gasol et al., 1991) to 49 cm by Cryptomonas spp. in Lake Arcas (Rodrigo et al., 1999; Camacho et al., 2001b). Regardless, growth and/or photosynthesis by Cryptomonas spp. would be inhibited by sulphide (Gasol et al., 1993; Camacho et al., 2001b), as it is the case for many photosynthetic organisms (Oren et al., 1979; Stal, 1995). These algae can spend the night in sulphide-rich anoxic waters, although in the absence of light they can be maintained by consuming previously accumulated carbohydrates (Gasol et al., 1993; Gervais et al., 1997), a process that does not seem to be inhibited even by relatively high sulphide concentrations (Gasol et al., 1991). These algae then migrate to oxic layers during the day to avoid sulphide inhibition to photosynthesis, which is not irreversible.

Some cyanobacteria are often associated with low redox conditions in several environments (Stal, 1995; Camacho et al., 2005). In lakes, their metalimnetic populations usually experience these low redox conditions since they are located at the oxycline, which usually coincides with the redoxcline. Low redox in lakes is promoted by the accumulation of reduced substances, and among these, sulphide could interfere photosynthesis of metalimnetic phototrophs (Stal, 1995; Camacho et al., 2000a, 2001b). Sulphide is especially abundant in the hypolimnion of those lakes presenting enough sulphate concentrations in their waters, allowing sulphate reduction to be the main anaerobic respiration 
pathway, with sulphate acting as electron acceptor of the respiration of organic matter in deep layers, thus resulting in sulphide accumulation at the hypolimnion. Karstic lakes lying totally or partly on gypsum $\left(\mathrm{CaSO}_{4}\right)$ substrate, like Lake Arcas, show these features (Fig. 1, Fig. 3A), in contrast with those lying on limestone (Fig. 3C), which usually present very low sulphide concentrations at the top part of the hypolimnion (Rodrigo, 1997). Cyanobacteria forming metalimnetic maxima in Spanish lakes (Table 1) usually belong to the genus Planktothrix (although some species were formerly described as belonging to the genus Oscillatoria; Anagnostidis \& Komárek, 1988) as in Lake Arcas (Fig. 1). This lake presents a sulphide-rich anoxic hypolimnion, where this cyanobacterium shows a relative resistance of their oxygenic photosynthesis to sulphide although their capacity for anoxygenic photosynthesis using sulphide as electron donor is almost negligible (Camacho et al., 1996). In this lake, its capacity for buoyancy regulation allow these cyanobacteria to migrate during the day (Rodrigo et al., 1999, Camacho et al., 2000a) to layers in which sulphide concentrations are not inhibitory for its oxygenic photosynthesis (Camacho et al., 1996). Therefore these cyanobacteria can considerably contribute to primary production at these layers (Camacho \& Vicente, 1998). Similar Oscillatoria-dominated DCM have been described in the metalimnion of other Spanish lakes with moderate to high sulphate concentrations, like in Lake Montcortes (Camps et al., 1976) and Lake Estanya (Avila et al., 1984), although in these cases their response to sulphide is unknown. Filamentous cyanobacteria contributing to the DCM have not only been reported, however, in systems that are relatively rich in sulphide. For instance, the metalimnetic Oscillatoria (Planktothrix) population from Lagunillo del Tejo (Vicente \& Miracle, 1984, Camacho et al., 2003a), a small karstic lake lying on limestone, experience very low sulphide concentrations, although redox potential is also very low because of the accumulation of reduced substances resulting from the decomposition of macrophytes surrounding the lake.
Even though it has been reported that certain species of both cryptophytes and cyanobacteria can have limited heterotrophic capabilities, the former by phagotrophy (Porter, 1988) and the latter by osmotrophy (Vincent \& Goldman, 1980), most studies searching for the capacity of these organisms for sustained heterotrophic growth have failed (e,g. Gervais, 1997a, 1998). Mixotrophy then (either phagotrophy or osmotrophy), when occurring, seems to represent a complementary mechanism allowing harvesting of certain substances or the maintenance during unfavourable periods (Bird \& Kalff, 1989; Tranvik et al., 1989; Jones, 2000; Laybourn-Parry et al., 2005).
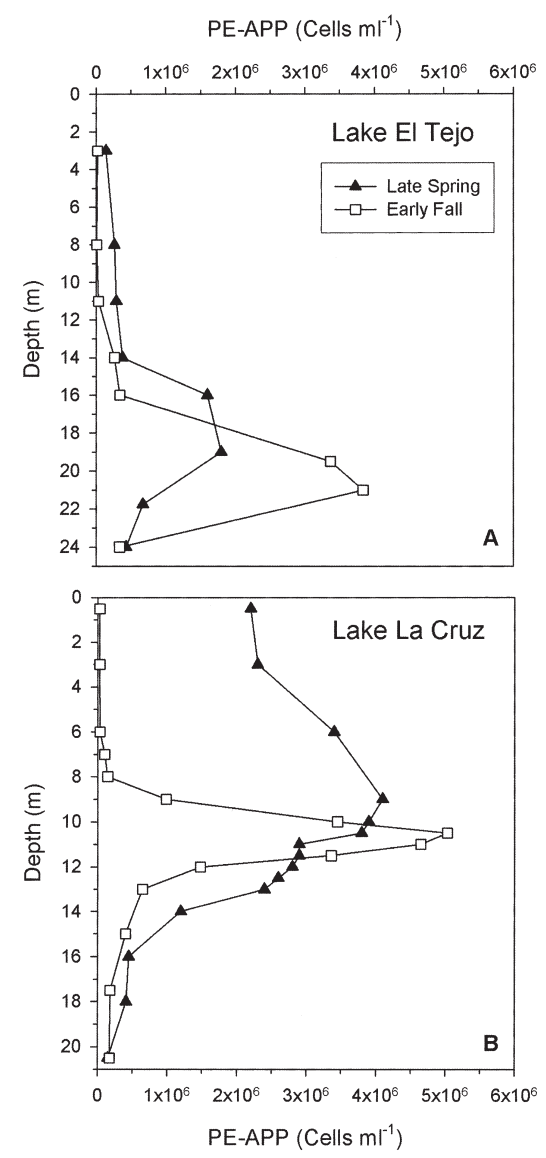

Figure 5. Vertical distribution of phycoerythrin-containing unicellular picocyanobacteria (PE-APP) at the beginning (spring) and end (fall) of the stratification period in (A) Lake El Tejo and (B) Lake La Cruz. Distribución vertical de las picocianobacterias unicelulares con ficoeritrina (PE-APP) al principio (primavera) y final (otoño) del periodo de estratificación en (A) Laguna del Tejo, y (B) Laguna de la Cruz. 
Contrastingly to Cryptomonas and filamentous cyanobacteria, which clearly develop DCM in most of the above reported Spanish lakes by in situ growth at the metalimnion, the mechanism for DCM maximum formation by phycoerythrin-containing unicellular picocyanobacteria (PE-APP) is not so clear, although the occurrence of DCM formed by these microorganisms has also been reported for several Spanish lakes (Camacho et al., 2003a). As an example, a comparison can be made for lakes El Tejo and La Cruz (Fig. 3C and Fig. 5), two deep karstic lakes lying on limestone and located just a few hundred meters from each other. Lake El Tejo is a holomictic lake of $27 \mathrm{~m}$ of maximum depth, where the oxic-anoxic interface usually establishes at $20 \mathrm{~m}$ depth during the period of maximal stability. In this lake, a DCM maximum formed by PE-APP typically reaching abundances of $4 \mathrm{x}$ $10^{6}$ cell ml-1 is found in the upper hypolimnion, whereas the abundance of these microorganisms, as well as Chl- $a$ concentrations in the epilimnion, are one order of magnitude lower during the whole stratification period (Camacho et al., 2003c; Morata et al., 2003). By contrast in Lake La Cruz, a meromictic lake of $21 \mathrm{~m}$ depth

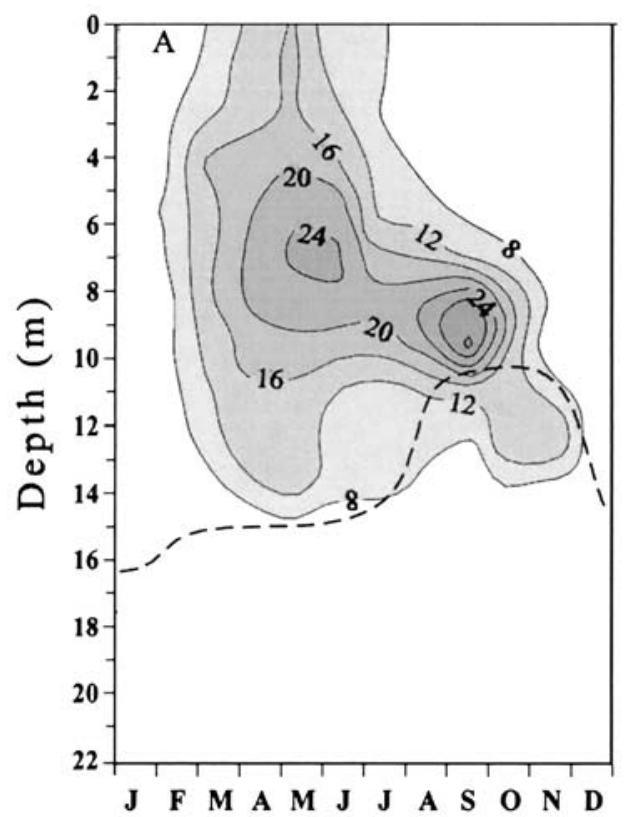

(Rodrigo et al., 2000b), dense populations of PE-APP of around 3-4 x $10^{6}$ cell $\mathrm{ml}^{-1}$ can develop both in the epilimnion and metalimnion in spring, and a clear DCM is not commonly easily recognizable at the beginning of the stratification period. Later on, the epilimnetic population of pìcocyanobacteria strongly decays as stratification advances and nitrogen depletion occurs in the epilimnion of this lake (Fig. 6), then a conspicuous DCM with dense PE-APP populations of up to $7 \times 10^{6}$ cell ml-1 becomes evident at the bottom part of the thermocline (Camacho et al., 2003b). Hence, in Lake La Cruz, the strong decrease in the abundance of unicellular picocyanobacteria in the epilimnion makes the DCM visible. This decrease could be due either to grazing, decomposition, or sedimentation, although the latter is only considered as an important loss factor for PE-APP when massive calcium precipitation causing whiting occurs (Miracle et al., 2000; Stockner et al., 2000; Camacho et al., 2003b), usually associated to a peak of Chl- $a$ deposition (Romero et al., 2006). In the case of Lake La Cruz, mechanisms other than in situ growth could contribute to explain the appearance of the DCM. In any case, PE-APP from DCM

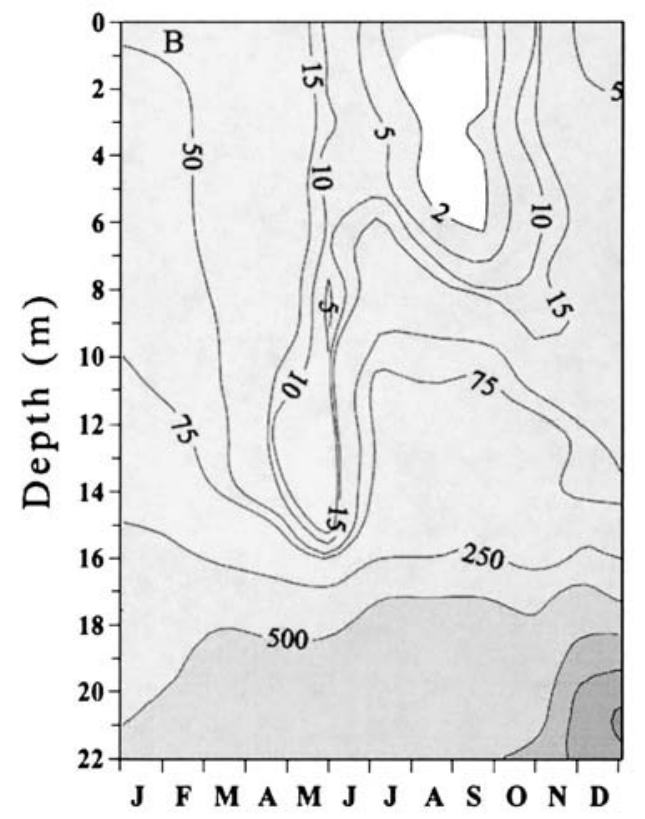

Figure 6. Isopleths of (A) chlorophyll- $a$ concentration and (B) dissolved inorganic nitrogen in Lake La Cruz during an annual cycle. Isolíneas de (A) concentración de clorofila-a, y (B) nitrógeno inorgánico disuelto, en la Laguna de la Cruz, durante un ciclo anual. 
are, as other phototrophs forming DCM, well adapted to low light conditions (Callieri et al., 1996; Stockner et al., 2000; Camacho et al. 2003c), thus performing well at the dim light field of the metalimnion of these lakes.

In most of the above reported Spanish lakes, phototrophic sulphur bacteria can also form dense populations beneath the DCM (Ávila et al., 1984; Gasol et al., 1991; Guerrero \& PedrósAlió, 1992; García-Gil et al., 1993, 1999; Camacho, 1997; Rodrigo, 1997; Rodrigo et al., 2000a, 2000b; Camacho et al., 2000b). Many of these bacteria have also the capacity for vertical migration (Gasol et al., 1991, Rodrigo et al., 1999), which means that they coexist, at least during part of the day, with metalimnetic algae and cyanobacteria. Consequently, competitive interactions for nutrients or light, as well as positive detoxification effects of sulphide by sulphur bacteria, can occur involving these microorganisms at the chemocline of these lakes.

Additionally to cryptophytes and cyanobacteria, other algae, such as dinoflagellates (e.g. Peridinium, Ceratium; Gálvez et al., 1988, 1993; Miracle et al., 1992, Echevarría \& Rodriguez, 1994) have also been described to form relative abundance maxima at the metalimnion of Spanish stratified lakes (Table 1). The dinoflagellate Ceratium hirundinella, a typical phytoplankter from highly mineralised reservoirs of south and east Spain (Margalef et al., 1976; Margalef et al., 1982; Armengol et al., 1991; Sabater \& Nolla, 1991), has also been described to form deep populations in several Spanish reservoirs. Gálvez et al., (1988) described a DCM in the eutrophic La Concepción reservoir (south Spain) mostly (in terms of biomass) formed by this dinoflagellate. As previously referred for cryptophytes, $C$. hirundinella also present the capacity for vertical movement (e.g. Taylor et al., 1988), allowing some control on its vertical position within the water column, as well as the capacity for behavioural aggregation, which together with the stability of the water column allowing nutrient regeneration at the thermocline were the main reasons argued by Gálvez et al., (1988) to explain the formation of this DCM in La Concepción reservoir.
Interestingly, Heaney et al., (1988) also described the high stability of the water column during stratification as a requisite for the development of Ceratium populations, which could be interpreted as a need for high temperatures (as in summer) and light availability in deep layers for this phytoplankter, the latter resulting from increased epilimnion transparency after nutrient exhaustion. Pérez-Martínez \& Sánchez-Castillo (2001, 2002), however, reported the winter dominance of $C$. hirundinella in reservoirs of southern Spain, although in these reservoirs light availability was also high during the mixing period, which together with their special hydrodynamic regimes could contribute to the appearance of this dinoflagellate. Additionally, and in contrast with cryptophytes, which are also flagellated algae forming DCM, Ceratium is known to avoid anoxic waters (Taylor et al., 1988), and consequently does not form these maxima in the vicinity of the oxycline.

Although diatoms have been described forming "deep chlorophyll layers" (DCL) in Spanish lakes (Miracle et al., 1992), probably resulting from settling, no absolute DCM formed by diatoms has been reported so far in Iberic lakes. Probably the best documented example of diatom-dominated DCL in Spain is that of the upper part of the metalimnion of Lake Arreo (Chicote, 2004). In this lake, Cyclotella distinguenda and other diatoms accompanied by the chlorophyte Monoraphidium minutum, the chrysophytes Pseudokephyrion conicum, and Dinobryon sertularia, and slightly shallower, by dinoflagellates (Peridinium spp.), formed a DCL overlying the metalimnetic maximum of Cryptomonas spp. Cryptomonas spp dominates at the DCM, whereas none of the mentioned species forming the shallower DCL could be considered as a real metalimnetic species since they commonly grew at the epilimnion and accumulated at the top part of the metalimnion when the density gradient reduces sinking velocities, except the diatoms Fragillaria capucina and Synedra ulna, which mainly appeared at the top layers of the metalimnion and not in upper layers. Nevertheless, the high relative number of empty diatom frustules found in these 
DCL would probably support the assertion that they were mainly resulting from settling. Chicote (2004) however, claimed that they could also respond to gradients in silica concentration. In clear-water lakes, such as alpine lakes from the Pyrenees, DCL, when occurring, are dominated by chrysophytes, like those from Lake Redó, although the relative importance of cryptophytes also increases with depth (Felip et al., 1999; Felip \& Catalán, 2000).

Flagellated unicellular chlorophytes (Chlamydomonas sp.) and chroococcal cyanobacteria (Gloeocapsa sp.), together with unicellular picocyanobacteria (PE-APP), have also been described to contribute to the DCM in Lake El Tobar (Miracle et al., 1993; García-Gil et al., 1999; Camacho et al., 2002), a crenogenic meromictic karstic lake with highly saline waters in deep layers (Vicente et al., 1993). Whereas cyanobacteria can produce phycobilins allowing light harvesting at deep layers, Chlamydomonas is unable to. The mixoheterotrophic capabilities of this alga (Laliberté \& de la Noüe, 1993; Gerloff-Elias et al., 2005) could perhaps contribute to its occurrence, since their higher population densities were found at a depth where a strong salinity (and density) gradient occurred. This gradient acting as a trap for particles settling from upper layers highly increases the availability of organic matter at these depths that could be used by these algae for heterotrophic growth. Other studies on DCM formed by Chlamydomonas though, have shown that its growth was mainly resulting from photosynthesis (Poerschmann et al., 2004). Chlamydomonas sp. and other flagellated chlorophytes, such as Pedinomonas sp., have been also described as peaking immediately above the DCM of other Spanish karstic lakes (Dasí and Miracle, 1991; Miracle et al., 1992)

Chlorella endosymbionts of ciliated protozoa have also been observed close to the oxic-anoxic interface of several Spanish lakes such as Lagunillo del Tejo (Camacho, unpublished) and Lake Cisó (Esteve et al., 1988; Guerrero \& Pedrós-Alió, 1992; Miracle et al., 1992), but in this lake its contribution to primary production was very low (Massana et al., 1996). Although they can certainly contribute to the DCM, they were accompanied by extremely dense populations of other phototrophic microorganisms, such as Cryptomonas and/or Oscillatoria (Planktothrix), which were very abundant at these depths and are responsible for most of the Chl- $a$ maximum in the reported lakes.

\section{LOW POPULATION LOSSES BY SINKING AS A FEATURE FOR MOTILE PHOTOTROPHS FORMING DCM}

A common feature of metalimnetic algae and cyanobacteria forming DCM by in situ growth close to the oxic-anoxic interfaces is that they usually have low population losses (Pedrós-Alió et al., 1987; Miracle et al., 1992; Massana et al., 1996). Theoretically, losses of a planktonic population could be mainly attributed to sinking, grazing, or decomposition. Even though that they are forming DCM and may synthesise phycoerythrin, in situ growth of metalimnetic phototrophs can be light limited (Camacho \& Vicente, 1998). Consequently, if population losses were high, growth rates could perhaps be too low for balancing losses and then a DCM would not be formed. Apparently, metalimnetic algae would not suffer important losses by sedimentation. Firstly, they can be located in a density gradient, which could help for the algal maintenance at a certain depth avoiding further sinking. Furthermore, they can present active or passive mechanisms to avoid settling, thus allowing algal accumulation. Whereas cryptophytes regulate the depth at which they are located by active flagellar movement, unicellular picocyanobacteria have a very low Reynolds number and are almost unaffected by sedimentation under regular stratification conditions (Stockner et al., 2000, Camacho et al., 2003b). Filamentous cyanobacteria, however, control buoyancy by means of gas vesicles and the accumulation of organic and/or inorganic substances acting as ballast (Konopka et al., 1993; Walsby, 1994). Among the DCM maxima described for Spanish lakes, the most detailed study with respect to possible sinking losses is that of the 
Oscillatoria (Planktothrix) population of Lake Arcas (Camacho et al., 1996, 2000a). As reported above, hypolimnetic waters of this lake are rich in sulphide and almost aphotic (Fig. 1), however this cyanobacterium can form dense populations at the lower metalimnion and through the hypolimnion. Camacho et al., (2000a) described a possible mechanism in which these cyanobacteria photosynthesise very actively at the oxic-anoxic interface where light availability is still sufficient (Camacho \& Vicente, 1998). At these depths sulphide concentrations are not yet inhibitory for their oxygenic photosynthesis (Camacho et al., 1996). When photosynthetic rates are high (exceeding growth) phototrophs can accumulate the excess of photosynthate in organic molecules such as glycogen (Konopka et al., 1993), which can act as ballast, promoting settling of the filament, which then enters the anoxic and aphotic hypolimnion. In the aphotic hypolimnion they cannot photosynthetise, but instead they are capable of accumulating nutrients in such a nutrient-richer environment, where cyanophycin or even phycobilins (as nitrogen reservoir) or volutine (polyphosphate) granules could be accumulated. Under anoxic conditions, many cyanobacteria are capable of anaerobic fermentation of glycogen (Stal \& Moezelaar, 1997). Anaerobic glycogen consumption would progressively reduce glycogen ballast while the cyanobacterium is also generating gas vesicles. Such gas vesicle formation and ballast (glycogen) consuming promotes an increase of the buoyancy of the filament, which would then move upwards reaching again the top of the population at the DCM, where the cycle will start again. With this mechanism, sinking losses in the cyanobacterial population of Lake Arcas would be minimised, and the dense cyanobacterial populations accounting for most of the DCM would develop and maintain through the stratification period. Since these cyanobacteria are almost unedible for the zooplankton dominating microaerobic (Miracle \& Armengol-Díaz, 1995; Esparcia et al., 2001) and anoxic layers (Finlay et al., 1991) of Lake Arcas, grazing losses are also negligible. Therefore, these cyanobacteria can form a dense population in spite of their relatively low growth rates compared to other coexisting phototrophic microorganisms (Camacho \& Vicente, 1998; Camacho et al., 2000a), with low losses being an essential factor. As for these cyanobacteria, Cryptomonas can also stay in the dark for prolonged periods by consuming starch granules (Morgan \& Kalff, 1975; Gervais, 1997a; Camacho et al., 2001b), which would allow their maintenance in deep layers of the lake during the time they spend in aphotic waters.

\section{CONTRIBUTION OF DCM TO PLANKTONIC CARBON FIXATION WITHIN THE LAKE AND TO THE ENERGY FLUX}

Some of the first studies on planktonic primary production in Spanish lakes already took into consideration deep primary production, showing that metalimnetic rates of carbon photo-assimilation can sometimes be even higher than those of the epilimnion (Planas, 1973, 1990).

Lakes presenting a DCM formed by in situ growth also present a vertical profile of photosynthetic activity sometimes coinciding with the maximal abundance of phototrophs (Capblanc, 1982; Wetzel, 2001). Only a few studies have been devoted to carefully study the relative contribution of phototrophs forming DCM to overall primary production of the lakes where they are present (e.g. Konopka, 1983). As mentioned, Planas (1973), in her Ph. D. Thesis advised by Professor Margalef, was a pioneer in the study of the vertical distribution of primary production in Spanish lakes with her study performed in Lake Banyoles. She found the highest rates of inorganic carbon photoassimilation at the metalimnion or upper hypolimnion during most of the stratification period (Planas, 1990). Following, I illustrate with some of the reported studies performed so far in some European lakes.

Primary production through the vertical profile was carefully determined several times in Lake Arcas (Camacho \& Vicente, 1998), where carbon fixation by metalimnetic and hypolimnetic microorganisms (Planktothrix and Crypto- 
monas forming a DCM plus purple sulphur bacteria peaking at the top part of the hypolimnion) was measured with detail, and extrapolations were made by considering lake hypsography to evaluate the relative contribution of the DCM to overall planktonic primary production. These calculations yielded that approximately $18 \%$ of the planktonic primary production during the stratification period could be attributed to metalimnetic and hypolimnetic microorganisms concentrated in just $1.5 \%$ of the lake water volume. Sixty five percent of this carbon photoassimilation at the metalimnion corresponded to purple sulphur bacteria and $35 \%$ to the oxygenic phototrophs. Incubations of samples at depths above or below that those where they were taken revealed that, in spite of having phycoerythrin or other highly-efficient light-harvesting systems, these populations were light limited.

In Lake Cadagno, a meromictic lake located in the Alps of Switzerland, primary production was studied with detail along a diel cycle in early September, corresponding to the moment of maximum stratification and lake stability (Camacho et al., 2001a). In this case, metalimnetic and hypolimnetic primary production showed a much higher relative contribution to planktonic primary production of up to $70 \%$ of the total carbon fixation within the lake, although almost half of the measured total inorganic carbon fixation in this lake was due to dark fixation. From inorganic carbon fixed photosynthetically in deep layers (41\% of overall lake's planktonic carbon photoassimilation), approximately $50 \%$ of the total was fixed anoxigenically by sulphur bacteria, whereas the remaining $50 \%$ was fixed by oxygenic phototrophs. The latter could be attributed mostly to Cryptomonas spp. forming a DCM at about $11.5 \mathrm{~m}$, whereas at the diatomdominated DCL located at $11 \mathrm{~m}$ carbon photoassimilation was much lower.

Other researchers also studied the relative contribution of algae from several depths to overall photosynthetic planktonic carbon assimilation in Spanish lakes. This is the case of Lake Arreo, where planktonic primary production was carefully measured within the vertical profile both during the annual cycle and through a diel cycle (Chicote, 2004). In this lake, it was estimated that metalimnetic photosynthetic primary production during the period of maximum stability, mainly performed by Cryptomonas spp., could account for up to a half of planktonic photosynthesis, despite that the volume of metalimnetic waters is approximately $1 / 4$ of that of the epilimnion. In Lake Arreo apparently all the algae forming DCL at different depths substantially contributed to primary production, and their relative contribution changed during the period of stratification, with the relative importance of the DCM formed by Cryptomonas increasing as stratification advanced. In this lake, however, the top part of the metalimnion was located at shallower depths $(3 \mathrm{~m})$ than, for instance, in lakes Arcas or Cadagno. Consequently, light availability was higher for algae lacking phycobilins and forming DCL at the top of the metalimnion, like diatoms, and especially dinoflagellates, whose maximal population densities at the top of the metalimnion coincided with peaks of inorganic carbon photoassimilation (Chicote, 2004). The higher light availability in comparison with other lakes could explain why their contribution to carbon fixation relative to the DCM located at the bottom part of the metalimnion or upper hypolimnion was higher. Nevertheless, in Lake Arreo, during the period of maximum productivity (early September) the absolute maxima of primary production within the vertical profile was associated to metalimnetic populations of Cryptomonas (Chicote, 2004), although the shallower peak of $C$. erosa showed higher photosynthetic rates (both in absolute values and specific carbon fixation per pigment unit) than the deepest formed by C. phaseolus, regardless of the period of the day.

In spite of commonly showing the absolute maxima of carbon photoassimilation, the populations of phototrophs forming DCM are usually light limited. Experiments made in Spanish lakes in which samples from the DCM were incubated at other depths resulted in considerable increases when these samples were incubated in shallower waters without significant variations in temperature but with substantial increases in light availability. Increases 
of carbon photoassimilation ranged from up to 2.5 times in Lake Arcas (Camacho and Vicente, 1998) to 26 times in Lake Arreo (Chicote, 2004). However, a certain photoinhibition was detected when these samples were incubated quite close to lake surface. Photosynthesis vs irradiance (P/I) curves allowed to estimated $\mathrm{I}_{\mathrm{k}}$ for these populations, which were $40 \mu \mathrm{E} \mathrm{m}^{-2} \mathrm{~s}^{-1}$ for the DCM formed by Cryptomonas of Lake Arreo, and as low as $12 \mu \mathrm{E} \mathrm{m}^{-2}$ $\mathrm{s}^{-1}$ for the metalimnetic maxima of phototrophs of Lake Arcas formed by Planktothrix, Cryptomonas and purple sulphur bacteria.

\section{ACKNOWLEDGEMENTS}

The author is much indebted to all the people who have contributed to the studies of the DCM in karstic lakes in Cuenca, especially to Eduardo Vicente and María Rosa Miracle, who initiated and are still active in this work, Toñi Rodrigo, Javier Armengol and Loles Boronat, whose Ph. D. work highly contributed to the knowledge of these lakes, and to a number of Ph. D. students such as Mari Loli Sendra, María Jose Dasí, Dani Sanchis, Antonio Picazo, Sara Morata, Lidia Romero and C. Rochera, whose research work during the last years was partly related to the DCM found in these lakes, as well as many others who occasionally contributed to these works. Financial support on which all this research was based was given by several grants from CICyT (Spanish Ministry of Education and Science) and by the Junta de Comunidades de Castilla - La Mancha, as well as by funds provided from the consulting activities of the author.

\section{REFERENCES}

ABBOTT, M., K. L. DENMAN, T. M POWELL, P. J. RICHERSON, R. C. RICHARDS \& C. R. GOLDMAN. 1984. Mixing and the dynamics of the deep chlorophyll maximum in Lake Tahoe. Limnol. Oceanogr., 29: 862-878.

ADLER, M., F. GERVAIS \& U. SIEDEL. 2000. Phytoplankton species composition in the chemo- cline of mesotrophic lakes. Arch. Hydrobiol. Spec. Issues Advanc. Limnol., 55: 513-530.

ADRIAN, R. \& T. SCHIPOLOWSKI. 2001. Bacterial and protozoan mass accumulation in the deep chlorophyll maximum of a mesotrophic lake. Arch. Hydrobiol., 157: 27-46.

ADRIAN, R., S. A. WICKHAM \& N. B. BUTLER. 2001. Trophic interactions between zooplankton and the microbial community in contrasting food webs: the epilimnion and deep chlorophyll maximum of a mesotrophic lake. Aquat. Microb. Ecol., 24: 83-97.

ALFONSO, M. T. \& M. R. MIRACLE. 1987. Variación temporal de las poblaciones zooplanctónicas de la laguna anóxica del Cisó (Girona). Limnetica, 3: 167-177.

ALMODOVAR, A., G. G. NICOLA \& M. NUEVO. 2004. Effects of a bloom of Planktothirix rubescens on the fish community of a Spanish reservoir. Limnetica, 23 167-178.

ALONSO, M. 1998. Las lagunas de la España peninsular. Limnetica, 15: 1-176.

ANAGNOSTIDIS, K. \& J. KOMÁREK. 1988. Modern approach to the classification system of cyanophytes. III. Oscillatoriales. Arch. Hydrobiol. Suppl. (Algological Studies 50-53), 80: 327-472.

ARMENGOL, J., J. L. RIERA \& J. A. MORGUI. 1991. Major ionic composition in the Spanish reservoirs. Verh. Internat. Verein Limnol., 24: 1363-1366.

ARMENGOL, X. \& M. R. MIRACLE. 2000. Diel vertical movements of zooplankton in Lake La Cruz (Cuenca, Spain). J. Plankton Res., 22: 16831703.

ARMENGOL, X., A. ESPARCIA \& M. R. MIRACLE. 1998. Rotifer vertical distribution in a strongly stratified lake: A multivariate analysis. Hydrobiologia, 387/388: 161-170.

ARMENGOL-DIAZ, J., A. ESPARCIA, E. VICENTE \& M. R. MIRACLE. 1993. Vertical distribution of planktonic rotifers in a karstic meromictic lake. Hydrobiologia, 255/256: 381-388.

ARVOLA, L., A. OJALA; F. BARBOSA \& S. I. HEANEY. 1991. Migration behaviour of three cryptophytes in relation to environmental gradients: an experimental approach. Brit. Phycol. J., 26: 361-373.

ARVOLA, L., K. SALONEN, P. KANKAALA \& A. LEHTOVAARA. 1992. Vertical distributions of bacteria and algae in a steeply stratified humic lake under high grazing pressure from Daphnia longispina. Hydrobiologia, 229: 253-269. 
AUER, M. T. \& K. D. POWELL. 2004. Heterotrophic bacterioplankton dynamics at a site off the southern shore of Lake Superior. J. Great Lakes Res., 30: 214-219.

ÁvilA, A., J. L. BURRELl, A. DOMINGO, E. FERNÁNDEZ, J. GODALL \& J. M. LLOPART. 1984. Limnología del lago Grande de Estanya. Oecol. Aquat., 7: 3-24.

BARBIERO, R. M. \& M. L. TUCHMAN. 2001. Results from the EPA's biological open waters surveillance program of the Lauretian Great Lakes: II. Deep chlorophyll maxima. J. Great Lakes Res., 27: $155-166$.

BARBIERO, R. P. \& M. L. TUCHMAN. 2004. The deep chlorophyll maximum in Lake Superior. $J$. Great Lakes Res., 30: 256-268.

BARONE, R. \& L. NASELLI-FLORES. 2003. Distribution and seasonal dynamics of Cryptomonads in Sicilian water bodies. Hydrobiologia, 502: 325-329.

BERNER T., Z. DUBINSKY, K. WHYMAN \& P. G. FALKOWSKY. 1989. Photoadaptation and the "package effect" in Dunaliella tertiolecta (Chlorophyceae). J. Phycol., 25: 70-78.

BIRD, D. F. \& J. KALFF. 1989. Phagotrophic sustenance of a metalimnetic phytoplankton peak. Limnol. Oceanogr., 34: 155-162.

BORONAT, M. D. \& M. R. MIRACLE. 1997. Size distribution of Daphnia longispina in the vertical profile. Hydrobiologia, 360: 187-196.

BØRSHEIM, K. Y., J. G. KUENEN; J. GOTSCHAL \& I. DUNDAS. 1985. Microbial activities and chemical gradients in the chemocline of a meromictic lake in relation to the precision of the sampling procedure. FEMS Microbiol. Ecol., 31: 337-341.

CALLIERI, C. \& M. L. PINOLINI. 1995. Picoplankton in lake Maggiore, Italy. Int. Revue ges. Hydrobiol., 80: 491-501.

CALLIERI C. \& R. PISCIA. 2002. Photosynthetic efficiency and seasonality of autotrophic picoplankton in Lago Maggiore after its recovery. Freshwater Biol., 47: 941-956

CALLIERI, C., E. AMICUCCI; R. BERTONI \& L. VÖRÖS. 1996. Fluorometric characterization of two picocyanobacteria strains from lakes of different underwater light quality. Int. Revue ges. Hydrobiol., 81: 13-23.

CAMACHO, A. 1997. Ecología de los microorganismos fotosintéticos en las aguas microaerobias y anóxicas de la Laguna de Arcas. Ph. D. Thesis, University of Valencia, Valencia, Spain. 360 pp.
CAMACHO, A. \& E. VICENTE. 1998. Carbon photoassimilation by sharply stratified phototrophic communities at the chemocline of Lake Arcas (Spain). FEMS Microbiol. Ecol., 25: 11-22.

CAMACHO, A., F. GARCÍA-PICHEL, E. VICENTE \& R. W. CASTENHOLZ. 1996. Adaptation to sulfide and to the underwater light field in three cyanobacterial isolates from Lake Arcas (Spain). FEMS Microbiol. Ecol., 21: 293-301.

CAMACHO, A., E. VICENTE \& M. R. MIRACLE. 2000a. Ecology of a deep-living Oscillatoria (= Planktothrix) population in the sulphide-rich waters of a Spanish karstic lake. Arch. Hydrobiol., 148: 333-355.

CAMACHO, A., E. VICENTE \& M. R. MIRACLE. 2000b. Spatio-temporal distribution and growth dynamics of phototrophic sulfur bacteria populations in a sulphide-rich lake (Lake Arcas, Spain). Aquat. Sci., 62: 334-349.

CAMACHO, A., J. EREZ, A. CHICOTE, M. FLORÍN, M. M. SQUIRES, C. LEHMANN \& R. BACHOFEN. 2001a. Microbial microstratification, inorganic carbon photoassimilation and dark carbon fixation at the chemocline of the meromictic Lake Cadagno (Switzerland) and its relevance to the food web. Aquat. Sci., 63: 91-106.

CAMACHO, A., E. VICENTE \& M. R. MIRACLE. 2001b. Ecology of Cryptomonas at the chemocline of a karstic sulphate-rich lake. Mar. Freshwater Res., 52: 805-815.

CAMACHO, A., E. VICENTE, L. J. GARCÍA-GIL, M. R. MIRACLE, M. D. SENDRA, X. VILA \& C. M. BORREGO. 2002. Factors determining changes in the abundance and distribution of nano- and picoplanktonic phototrophs in Lake El Tobar (Central Spain). Verh. Internat. Verein. Limnol., 28: 613-619.

CAMACHO, A., M. R. MIRACLE \& E. VICENTE. 2003a. Which factors determine the abundance and distribution of picocyanobacteria in inland waters? A comparison among different types of lakes and ponds. Arch. Hydrobiol., 157: 321-338.

CAMACHO, A., A. PICAZO, M. R. MIRACLE \& E. VICENTE. 2003b. Spatial distribution and temporal dynamics of picocyanobacteria in a meromictic karstic lake. Arch. Hydrobiol. Suppl. (Algol. Stud. 109) 148: 171-184.

CAMACHO, A., W. A. WURTSBAUGH, M. R. MIRACLE, X. ARMENGOL \& E. VICENTE. 2003c. Nitrogen limitation for phytoplankton in a Spanish Karst lake with a deep chlorophyll maximum: a nutrient enrichment bioassay approach. $J$. Plankton Res., 25: 397-404. 
CAMACHO, A., C. ROCHERA, J. J. SILVESTRE, E. VICENTE \& M. W. HAHN. 2005. Spatial dominance and inorganic carbon assimilation by conspicuous autotrophic biofilms in a physical and chemical gradient of a cold sulfurous spring: The role of differential ecological strategies. Microbial Ecol., 50: 172-184.

CAMARERO, LL.. M. FELIP, M. VENTURA, F. BARTUMEUS \& J. CATALÁN. 1999. The relative importance of the planktonic food web in the carbon cycle of an oligotrophic mountain lake in a poorly vegetated catchment (Redó, Pyrenees). $J$. Limnol., 58: 203-212.

CAMPS, J., I. GONZALVO; J. GÜELL; P. LÓPEZ; A. TEJERO; X. TOLDRÁ; F. VALLESPINOS \& M. VICENS. 1976. El lago de Montcortés, descripción de un ciclo anual. Oecol. Aquat., 2: 99-110.

CAPBLANC, J. 1982. Phytoplankton et production primaire. In: Ecologie du plancton des eaux continentales. Pourriot, R.; J. Capblanc, P. Champ \& J. A. Meyer (eds.).: 1-48. Paris, Mason.

CARRICK, H. J. \& G. L. FAHNESTIEL. 1989. Biomass, size structure, and compostition of phototrophic and heterotrophic nanoflagellate communities in Lake Huron and Michigan. Can. J. Fisheries Aquat. Sci., 46: 1922-1928.

CATALÁN, J., E. BALLESTEROS; L. CAMARERO; M. FELIP \& E. GACIA. 1992. Limnology in the Pyrenean lakes. Limnetica, 8: 27-38.

COLE, P. C., C. LUECKE, W. A. WURSTBAUGH \& G. BURKART. 2002. Growth and survival of Daphnia in epilimnetic and metalimnetic water from oligotrophic lakes: the effects of food and temperature. Freshwater Biol., 47: 2113-2122.

CRAIG, S. R. 1987. The distribution and contribution of picoplankton to deep photosynthetic layers in some meromictic lakes. Acta. Acad. Aboensis., 47: 55-81.

CHICOTE, A. 2004. Limnología y ecología microbiana del Lago de Arreo (Álava, España). Ph. D. Thesis, Universidad Autónoma de Madrid, Cantoblanco, $296 \mathrm{pp}$.

CHRISTENSEN, D. L., S. R. CARPENTER \& K. L. COTTINGHAM. 1995. Predicting chlorophyll vertical distribution in response to epilimnetic nutrient enrichment in small stratified lakes. $J$. Plankton Res., 17: 1461-1477.

CULLEN, J. J. 1982. The deep chlorophyll maximum: comparing vertical profiles of chlorophyll a. Can. J. Fisheries Aquat. Sci., 39: 791-803.

DASÍ, M. J. \& M. R. MIRACLE. 1991. Distribución vertical y variación estacional del fitoplancton de una laguna carstica meromíctica, la Laguna de la Cruz, (Cuenca, España). Limnetica, 7: 37-59.

DASÍ, M. J., M. R. MIRACLE, A. CAMACHO, J. M. SORIA \& E. VICENTE. 1998. Summer phytoplankton assemblages across trophic gradients in hardwater reservoirs. Hydrobiologia, 369/370: 27 - 43.

DAVEY, M. C. \& S. I. HEANEY. 1989. The control of sub-surface maxima of diatoms in a stratified lake by physical, chemical and biological factors. J. Plankton Res., 11: 1185-1199.

ECHEVARRÍA, F. \& J. RODRÍGUEZ. 1994. The size structure of plankton during a deep bloom in a stratified reservoir. Hydrobiologia, 284: 113-124.

ESPARCIA, A., J. ARMENGOL, E. VICENTE, \& M. R. MIRACLE. 1991. Vertical distribution of Anuraeopsis species as related to oxygen depletion in two stratified lakes. Verh. Internat. Verein. Limnol., 24: 2745-2749.

ESPARCIA, A., X. ARMENGOL \& M.R. MIRACLE. 2001. Relación de la distribución de los rotíferos con la de los principales factores físicos y químicos en la laguna de la Cruz. Limnetica, 20 305-320.

ESTEBAN, G., B. J: FINLAY \& T. M. EMBLEY. 1993. New species double the diversity of anaerobic ciliates in a Spanish lake. FEMS Microbiol. Lett., 109: 93-100.

ESTEVE, I., J. MIR; N. GAJU; H. I. MCHANN \& L. MARGULIS. 1988. Green endosymbiont of Coleps from Lake Cisó identified as Chlorella vulgaris. Symbiosis, 6: 197-210.

FAHNENSTIEL, G. L. \& J. M. GLIME. 1983. Subsurface chlorophyll maximum and associated Cyclotella pulse in Lake Superior. Int. Revue ges. Hydrobiol., 68: 605-616.

FALKOWSKI, P. G. \& J. A. RAVEN. 1997. Aquatic photosynthesis. Blackwell Science, Malden, Massachusetts. 375 pp.

FEE, E. J. 1976. The vertical and seasonal distribution of chlorophyll in lakes of the experimental lakes area, north western Ontario: implications for primary production. Limnol. Oceanogr., 21: 767-783.

FELIP, M. \& J. CATALÁN. 2000. The relationship between phytoplankton biovolume and chlorophyll in a deep oligotrophic lake: decoupling in their spatial and temporal maxima. J. Plankton Res., 22: 91-105.

FELIP, M., F. BARTUMEUS, S. HALAC \& J. CATALÁN. 1999. Microbial plankton assemblages, composition and biomass, during two ice-free periods in a deep high mountain lake (Estany Redó, Pyrenees). J. Limnol., 58: 193-202. 
FENCHEL, T. \& B. J. FINLAY. 1991. The biology of free-living anaerobic ciliates. Eur. J. Protistol., 26: 201-215.

FENNEL, K. \& E. BOSS. 2003. Subsurface maxima of phytoplankton and chlorophyll: steady-state solutions from a simple model. Limnol. Oceanogr., 48: 1521-1534.

FINLAY, B. J., K. J. CLARKE, E. VICENTE \& M. R. MIRACLE. 1991. Anaerobic ciliates from a sulphide-rich solution lake in Spain. Eur. J. Protistol., 27: 148-159.

GÁlVEZ, J. A., F. X. NIELL \& J. LUCENA. 1988. Description and mechanism of formation of a deep chlorophyll maximum due to Ceratium hirundinella. (O. F. Müller). Arch. Hydrobiol., 112: 143-155.

GALVEZ, J. A., F. X. NIELL \& J. LUCENA. 1993. Sinking velocities of principal phytoplankton species in a stratified reservoir: ecological implications. Verh. Internat. Verein Limnol., 25: 1228-1231.

GARCÍA-GIL, L. J. \& A. CAMACHO. 2001. Anaerolimnología: pequeña guía para el muestreo en aguas microaeróbicas y anóxicas en lagos y embalses estratificados. Limnetica, 20: 179-186.

GARCÍA-GIL, L. J., C. M. BORREGO; L. BAÑERAS \& C. A. ABELLÀ. 1993. Dynamics of phototrophic microbial populations in the chemocline of a meromictic basin of lake Banyoles. Int. Revue ges. Hydrobiol., 78: 283-293.

GARCÍA-GIL, L. J., E. VICENTE, A. CAMACHO, C. M. BORREGO, X. VILA, X. P. CRISTINA, \& J. RODRÍGUEZ-GONZÁLEZ. 1999. Vertical distribution of photosynthetic sulphur bacteria linked to saline gradients in Lake El Tobar (Cuenca, Spain). Aquat. Microb. Ecol., 20: 299-303.

GASOL, J. M., J. GARCIA-CANTIZANO; R. MASSANA; F. PETERS; R. GUERRERO \& C. PEDRÓS-ALIÓ. 1991. Diel changes in the microstratification of the metalimnetic community in lake Cisó. Hydrobiologia, 211: 227-240.

GASOL, J. M., R. GUERRERO \& C. PEDRÓSALIÓ. 1992. Spatial and temporal dynamics of a metalimnetic Cryptomonas peak. J. Plankton Res., 14: $1565-1580$.

GASOL, J. M., J. GARCÍA-CANTIZANO; R. MASSANA; R. GUERRERO \& C. PEDRÓS-ALIÓ. 1993. Physiological ecology of a metalimnetic Cryptomonas population: relationships to light, sulfide and nutrients. J. Plankton Res., 15: 255-275.

GASOL, J. M., K. JÜRGENS; R. MASSANA; J. I. CALDERÓN-PAZ \& C. PEDRÓS-ALIÓ. 1995. Mass development of Daphnia pulex in a sulfide- rich pond (Lake Cisó). Arch. Hydrobiol., 132: 279-296.

GERLOFF-ELIAS, A. E. SPIJKERMAN \& H. SCHUBERT. 2005. Light acclimation of Chlamydomonas acidophila accumulating in the hypolimnion of an acidic lake (pH 2.6). Freshwater Biol., 50: 13011314.

GERVAIS, F. 1991. Which factors control seasonal and spatial distribution of phytoplankton species in Schlachtensee (Berlin, FRG.)? Arch. Hydrobiol., 121: 43-65.

GERVAIS, F. 1997a. Light-dependent growth, dark survival, and glucose uptake by cryptophytes isolated from a freshwater chemocline. J. Phycol., 33: $18-25$.

GERVAIS F. 1997b. Diel vertical migration of Cryptomonas and Chromatium in the deep chlorophyll maximum of a eutrophic lake. J. Plankton Res., 19: 533-550.

GERVAIS F. 1998. Ecology of cryptophytes coexisting near a freshwater chemocline. Freshwater Biol., 39: 61-78.

GERVAIS, F. 2001. Fine-scale analysis of a deep chlorophyll maximum. Verh. Internat. Verein. Limnol., 27: 932-935.

GERVAIS F., J. PADISÁK \& R. KOSCHEL. 1997. Do light quality and low nutrient concentration favour picocyanobacteria below the thermoclime of the oligotrophic Lake Stechlin? J. Plankton Res., 19: 771-781.

GERVAIS, F., U. SIEDEL, B. HEILMANN, G. WEITHOFF, G. HEISIG-GUNKEL \& A. NICKLISCH. 2003. Small-scale vertical distribution of phytoplankton, nutrients and sulphide below the oxycline of a mesotrophic lake. J. Plankton Res., 25: 273-278

GONZÁLEZ-MOZO, M. E., A. CHICOTE, E. RICO \& C. MONTES. 2000. Limnological characterization of an evaporite karstic lake in Spain (Lake Arreo). Limnetica, 18: 91-98.

GUERRERO, R. \& C. PEDRÓS-ALIÓ. 1992. The microbial component in Spanish aquatic ecosystems. Limnetica, 8: 175-184.

HEANEY, S. I., J. W. G. LUND, H. M. CANTER \& K. GRAY. 1988. Population dynamics of Ceratium spp. in three English lakes, 1945-1985. Hydrobiologia, 161: 33-148.

JACKSON, L. S., J. G. STOCKNER \& P. J. HARRISON. 1990. Contribution of Rhizosolenia eriensis and Cyclotella spp. to the deep chlorophyll maximum of Sproat lake, British Columbia, Canada. Can. J. Fisheries Aquat. Sci., 47: 128-135. 
JONES, R. I. 1991. Advantages of diurnal vertical migrations to phytoplankton in sharply stratified, humic forest lakes. Arch. Hydrobiol., 120: 257-266.

JONES, R. I. 1993. Phytoplankton migrations: Patterns, processes and profits. Arch. Hydrobiol. Beih. Ergebn. Limnol., 39: 67-77.

JONES, R.I. 2000. Mixotrophy in planktonic protists: an overview. Freshwater Biol., 45: 219-226.

JØRGENSEN, B. B., J. G. KUENEN \& Y. COHEN. 1979. Microbial transformations of sulfur compounds in a stratified lake (Solar Lake, Sinai). Limnol. Oceanogr., 24: 799-822.

KARENTZ, D., M. L. BOTHWELL, R. B. COFFIN, A. HANSON, G. J. HERNDL, S. S. KILHAM, M. P. LESSER, M. LINDELL, R. E. MOELLER, D. P. MORRIS, P. J. NEALE, R. W. SANDERS, C. S. WEILER \& R. G. WETZEL. 1994. Impact of UV-B radiation on pelagic freshwater ecosystems: Report of working group on bacteria and phytoplankton. Arch. Hydrobiol. Beih. Ergebn. Limnol., 43: 31-69.

KASPRZAK., P., F. GERVAIS, R. ADRIAN, W. WEILER, R. RADKE, I. JAGER, S. RIEST, U. SIEDEL, B. SCHNEIDER, M. BOHME, R. ECKMANN \& N. WALZ. 2000. Trophic characterization, pelagic food web structure and comparison of two mesotrophic lakes in Brandenburg (Germany). Internat. Rev. Hydrobiol., 85: 167-189.

KESSLER, K. \& W. LAMPERT. 2004. Fitness optimization of Daphnia in a trade-off between food and temperature. Oecologia, 140: 381-387.

KETTLE, W. D., M. F. MOFFETT, \& F. DENOYELLES. 1987. Vertical distribution of zooplankton in an experimentally acidified lake containing a metalimnetic phytoplankton peak. Can. J. Fish. Aquatic Sci., 44: 91-95.

KING, C. E. \& M. R. MIRACLE. 1995. Diel vertical migration by Daphnia longispina in a Spanish lake: genetic sources of distributional variations. Limnol. Oceanogr, 40: 226-231.

KONOPKA, A. 1982. Physiological ecology of a metalimnetic Oscillatoria rubescens population. Limnol. Oceanogr., 27: 1154-1161.

KONOPKA, A. 1983. Epilimnetic and metalimnetic primary production in an Indiana hardwater lake. Can. J. Fish. Aquat. Sci., 40: 792-798.

KONOPKA, A. 1989. Metalimnetic cyanobacteria in hard-water lakes: Buoyancy regulation and physiological state. Limnol. Oceanogr., 34: 1174-1184.

KONOPKA, A., A. R. KLEMER; A. E. WALSBY \& B. W. IBELINGS. 1993. Effects of macronutrients upon buoyancy regulation by metalimnetic
Oscillatoria agardhii in Deming Lake, Minnesota. J. Plankton Res., 15: 1019-1034.

KOSTE, W. 1991. Anuraeopsis miraclei. A new planktonic rotifer species in karstic lakes. Hydrobiologia, 209: 169-173.

LALIBERTE G. \& J. DE LA NOÜE. 1993. Auto-, hetero-, and mixotrophic growth of Chlamydomonas humicola (Chlorophyceae) on acetate. $J$. Phycol. 29: 612-620.

LAMPERT, W. \& J. GREY. 2003. Explotation of a deep-water algal maximum by Daphnia: a stableisotope tracer study. Hydrobiologia, 500: 95-101.

LASS, S., M. BOERSMA \& P. SPAAK. 2000. How do migrating Daphnids cope with fish predation risk in the epilimnion under anoxic conditions in the hypolimnion? J. Plankton Res., 22: 1411-1418.

LAYBOURN-PARRY, J., W. A. MARSHALL \& H. J. MARCHANT. 2005. Flagellate nutritional versatility as a key to survival in two contrasting Antarctic saline lakes. Freshwater Biol., 50: 830-838.

LINDHOLM, T. 1992. Ecological role of depth maxima of phytoplankton. Arch. Hydrobiol. Beih. Ergebn. Limnol., 35: 33-45.

MARGALEF, R. 1976. Biología de los embalses. Investigación y Ciencia, 10: 51-62.

MARGALEF, R. 1983. Limnología. Omega. Barcelona, $1010 \mathrm{pp}$.

MARGALEF, R., M. D. PLANAS; J. ARMENGOL, A. VIDAL, N. PRAT, A. GUISSET; J. TOJA \& M. ESTRADA. 1976. Limnologia de los embalses españoles. Dirección General de Obras Hidráulicas. MOP. Madrid. Pub. 123. 422 pp.

MARGALEF, R., M. MIR \& M. ESTRADA. 1982. Phytoplankton composition and distribution as an expression of properties of reservoirs. Can. W. Res., 7: 26-50.

MASSANA, R. \& C. PEDRÓS-ALIÓ. 1994. Role of anaerobic ciliates in planktonic food webs: abundance, feeding, and impact on bacteria in the field. Appl. Environ. Microbiol., 60: 1325-1334.

MASSANA, R., J. M. GASOL, K. JÜRGENS \& C. PEDRÓS-ALIÓ. 1994 Impact of Daphnia pulex on a metalimnetic microbial community. J. Plankton Res., 16: 1379-1399.

MASSANA, R., J. GARCÍA-CANTIZANO \& C. PEDRÓS-ALIÓ. 1996. Components, structure and fluxes of the microbial food web in a small, stratified lake. Aquat. Microb. Ecol., 11: 279-288.

MIRACLE, M. R. \& I. GONZALVO. 1979. Els llacs càrstics. Quad. Ecol. Apl., 4: 37-50.

MIRACLE, M. R. \& E. VICENTE. 1983. Vertical distribution and rotifer concentrations in the che- 
mocline of meromictic lakes. Hydrobiologia, 104: 259-267.

MIRACLE, M. R. \& M. T. ALFONSO. 1993. Rotifer vertical distributions in a meromictic basin of Lake Banyoles (Spain). Hydrobiologia, 255/256: 371-380.

MIRACLE, M. R. \& X. ARMENGOL-DÍAZ. 1995. Population dynamics of oxiclinal species in lake Arcas-2 (Spain). Hydrobiologia, 313/314: 291-301.

MIRACLE, M. R., E. VICENTE \& C. PEDRÓSALIÓ. 1992. Biological studies of Spanish meromictic and stratified lakes. Limnetica, 8: 59-77.

MIRACLE, M. R., J. ARMENGOL \& M. J. DASÍ. 1993. Extreme meromixis determines strong differential planktonic vertical distributions. Verh. Internat. Verein. Limnol., 25: 705-710.

MIRACLE, M. R., A. CAMACHO, R. JULIÀ \& E. VICENTE. 2000. Sinking processes and their effect on the sedimentary record in the meromictic Lake La Cruz (Spain). Verh. Internat. Verein. Limnol., 27: 1209-1213.

MODENUTTI, B., E. BALSEIRO, C. CALLIERI, C. QUEIMALINOS \& R. BERTONI. 2004. Increase in photosynthetic efficiency as a strategy of planktonic organisms exploiting deep lake layers. Freshwater Biol., 49: 160-169

MODENUTTI B. E, E. G. BALSEIRO, C. CALlIERI, R. BERTONI \& C. QUEIMALIÑOS. 2005. Effect of UV-B and different PAR intensities on the primary production of the mixotrophic planktonic ciliate Stentor araucanus. Limnol. Oceanogr., 50: 864-871.

MOLL, R. A. \& E. F. STOERMER. 1982. A hypothesis relating trophic status and subsurface chlorophyll maxima of lakes. Arch. Hydrobiol. 4: 425-440.

MORALES-BAQUERO, R., P. CARRILLO, L. CRUZ-PIZARRO \& P. SÁNCHEZ-CASTILLO. 1992. Southernmost high mountain lakes in Europe (Sierra Nevada) as reference sites for pollution and climate change monitoring. Limnetica, 8: 39-47.

MORATA, S. M., A. CAMACHO, M. R. MIRACLE \& E. VICENTE. 2003. Asociaciones fitoplanctónicas y su periodicidad en un lago marcadamente estratificado. Limnetica, 22: 35-52.

MORGAN, R. \& J. KALFF. 1975. The winter dark survival of an algal flagellate, Cryptomonas erosa (Skuja). Verh. Internat. Verein. Limnol., 19: 27342740 .

MOYÁ, G., G. BENNASAR; C. FRAU; L. GARCÍA, M. GOMEZ \& G. RAMÓN. 1993. Long term changes (after twelve years) in the composition of phytoplankton communities in the Gorg
Blau reservoir (Majorca, Spain). Verh. Internat. Verein Limnol., 25: 1257-1261.

NASELLI-FLORES, L., J. PADISÁK, M. T. DOKULIL \& I. CHORUS. 2003. Equilibrium/steadystate concept in phytoplankton ecology. Hydrobiologia 502: 395-403.

NEALE, P. J., E.LITCHMAN, C. SOBRINO, C. CALLIERI, G. MORABITO, V. MONTECINO, Y. HUOT, P. BOSSARD, C. LEHMANN \& D. STEINER. 2001. Quantifying the response of phytoplankton photosynthesis to ultraviolet radiation: Biological weighting functions versus in situ measurements in two Swiss lakes. Aquat. Sci., 63: 265-285.

NEGRO, A. I. \& C. DE HOYOS. 2005. Relationships between diatoms and the environment in Spanish reservoirs. Limnetica, 24: 133-144.

NYGAARD, G. 1996. Temporal and spatial development of individual species of plankton algae from European lakes. Hydrobiologia, 332: 71-91.

OREN, A., E. PADAN \& S. MALKIN. 1979. Sulfide inhibition of photosystem II in cyanobacteria (blue-green algae) and tobacco chloroplasts. Biochem. Biophys. Acta., 546: 270-279.

PADISÁK J., L. KRIENITZ, W. SCHEFFLER, R. KOSCHEL, J. KRISTIANSEN \& I. GRIGORSZKY. 1998. Phytoplankton succession in the oligotrophic Lake Stechlin (Germany) in 1994 and 1995. Hydrobiologia, 370: 179-197.

PEDRÓS-ALIÓ, C., J. M. GASOL \& R. GUERRERO. 1987. On the ecology of a Cryptomonas phaseolus population forming a metalimnetic bloom in lake Cisó, Spain: Annual distribution and loss factors. Limnol. Oceanogr., 32: 285-298.

PEDRÓS-ALIÓ, C., R. MASSANA, M. LATASA, J. GARCÍA-CANTIZANO \& J. M. GASOL. 1995. Predation by ciliates on a metalimnetic Cryptomonas population: feeding rates, impact and effects of vertical migration. J. Plankton Res., 17: 2131-2154.

PÉREZ-MARTÍNEZ, C. \& P. SÁNCHEZ-CASTILLO. 2001. Temporal occurrence of Ceratium hirundinella in Spanish reservoirs. Hydrobiologia, 452: 101-107.

PÉREZ-MARTÍNEZ, C. \& P. SÁNCHEZ-CASTILLO. 2002. Winter dominance of Ceratium hirundinella in a southern north-temperate reservoir. $J$. Plankton Res., 24: 89-96.

PICK, F. R. 1984. Photosynthesis and respiration of a metalimnetic chrysophyte population. Verh. Internat. Verein Limnol., 22: 326-331.

PICK, F. R., C. NALEWAJKO \& D. R. S. LEAN. 1984. The origin of metalimnetic chrysophyte peak. Limnol. Oceanogr., 29: 125-134. 
PILATI, A. \& W. A. WURTSBAUGH. 2003. Importance of zooplankton for the persistence of a deep chlorophyll layer: A limnocorral experiment. Limnol. Oceanogr., 48: 249-260.

PLANAS, M. D. 1973. Composición, ciclo y productividad del fitoplancton del Lago de Banyoles. Oecol. Aquat., 1: 3-106.

PLANAS, D. 1990. Factores de control de la distribución espacial y temporal de la producción primaria del fitoplancton del Lago de Banyoles. Scientia Gerundensis, 16: 193-204.

POERSCHMANN, J., E. SPIJKERMAN \& U. LANGER. 2004. Fatty acid patterns in Chlamydomonas sp. as a marker for nutritional regimes and temperature under extreme acidic conditions. Microbial Ecol., 48: 78-89.

PORTER, K. G. 1988. Phagotrophic phytoflagellates in microbial food webs. Hydrobiologia, 159: 89-97.

QUEIMALIÑOS C. P., B. E. MODENUTTI. \& E. G. BALSEIRO 1999. Symbiotic association of the ciliate Ophrydium naumanni with Chlorella causing a deep chlorophyll a maximun in an oligotrophic South Andes lake. J. Plankton Res., 21: 167-178.

RAMÓN, G. \& G. MOYÁ. 1984. Seasonal variations in the vertical distribution of Oscillatoria rubescens D.C. in the Gorg Blau reservoit, Spain. Verh. Internat. Verein Limnol., 22: 1546-1549.

RAVEN, J. A. \& K. RICHARDSON. 1984. Dinoflagellate flagella: A cost-benefit analysis. New Phytologist, 98: 259-276.

REYNOLDS, C. S. 1992. Dynamics, selection and composition of phytoplankton in relation to vertical structure in lakes. Arch. Hydrobiol. Beih. Ergebn. Limnol., 35: 13-31.

REYNOLDS, C. S. 1994. The long, the short and the stalled: on the attributes of phytoplankton selected by physical mixing in lakes and rivers. Hydrobiologia, 289: 9-21.

REYNOLDS, C. S. 1997. Vegetation processes in the pelagic. A model for ecosystem theory. ECI, Oldendorf. $404 \mathrm{pp}$.

REYNOLDS, C. S., V. HUSZAR, C. KRUK, L. NASELLI-FLORES \& S. MELO. 2002. Towards a functional classification of the freshwater phytoplankton J. Plankton Res., 24: 417-428.

RICO, E., A. CHICOTE, M. E. GONZÁLEZ \& C. MONTES. 1995. Batimetría y análisis morfométrico del lago de Arreo (N. España). Limnetica, 11: 55-58.

RIERA, J. L., D. JAUME, J. DE MANUEL, J. A. MORGUI \& J. ARMENGOL. 1992. Patterns of variation in the limnology of Spanish reservoirs: a regional study. Limnetica, 8: 111-124.
RODRIGO, M. A. 1997. Limnología comparada de las lagunas de dos sistemas cársticos de Cuenca: Bacterias fotosintéticas de la Laguna de La Cruz y la Laguna de Arcas-2 Ph. D. Thesis. Universitat de València. España. 521 pp.

RODRIGO, M. A., A. CAMACHO, E. VICENTE \& M. R. MIRACLE. 1999. Microstratified vertical distribution and migration of phototrophic microorganisms during a diel cycle in Lake Arcas-2 (Spain). Arch. Hydrobiol., 145: 497-512.

RODRIGO, M. A., E. VICENTE \& M. R. MIRACLE. 2000a. The physical, chemical, and biological characteristics of the holomictic sulphated lake Arcas-2 (Cuenca, Spain). Hydrobiologia, 418: 153-168.

RODRIGO, M. A., E. VICENTE \& M. R. MIRACLE. 2000b. The role of light and concentration gradients in the vertical stratification and seasonal development of phototrophic bacteria in a meromictic lake. Arch. Hydrobiol., 148: 533-548.

ROJO, C. \& M. R. MIRACLE. 1987. Poblaciones fitoplanctónicas de la Laguna de La Cruz (Cuenca), una laguna cárstica meromíctica. Act. VI Simp. Nac. Bot. Crip., 119-135.

ROJO, C. \& M. ÁlVAREZ-COBELAS. 2003. Are there steady-state phytoplankton assemblages in the field? Hydrobiologia, 502: 3-12.

ROMERO, L., A. CAMACHO, E. VICENTE \& M. R. MIRACLE. 2006. Sedimentation patterns of photosynthetic bacteria based on pigment markers in meromictic Lake La Cruz (Spain): Paleolimnological implications. J. Paleolimnol., 35: 167-177.

ROTT, E. 1988. Some aspects of the seasonal distribution of flagellates in mountain lakes. Hydrobiologia, 161: 159-170.

ROWAN, K. S. 1989. Photosynthetic pigments of algae. Cambridge University Press. 334 pp.

SABATER, S. \& J. NOLLA. 1991. Distribution patterns of phytoplankton in Spanish reservoirs: first results and comparison after fifteen years. Verh. Internat. Verein Limnol., 24: 1

SALONEN, K., R. I. JONES \& L. ARVOLA. 1984. Hypolimnetic phosphorus retrieval by diel vertical migrations of lake phytoplankton. Freshwat. Biol., 14: 431-438.

SAWATZKY, C. L., W. A. WURTSBAUGH \& C. LUECKE. 2006. The spatial and temporal dynamics of deep chlorophyll layers in high-mountain lakes: effects of nutrients, grazing, and herbivore nutrient recycling as growth determinants. $J$. Plankton Res., 28: 65-86. 
SOMMARUGA, R. 2001. The role of solar UV radiation in the ecology of alpine lakes. $J$. Photochem. Photobiol., B. 62: 35-42.

ST. AMAND, A. \& S. R. CARPENTER. 1993. Metalimnetic phytoplankton dynamics. In: The trophic cascade in lakes. Carpenter, S. R. \& J. F. Kitchell (eds.).: 210-224. Cambridge University Press, Cambridge.

STAL, L. J. 1995. Physiological ecology of cyanobacteria in microbial mats and other communities. New Phytol., 131: 1-32.

STAL, L. J. \& R. MOEZELAAR. 1997. Fermentation in cyanobacteria. FEMS Microbiol. Rev., 21: 179-211.

STOCKNER, J. G., C. CALLIERI \& G. CRONBERG. 2000. Picoplankton and other non-bloomforming cyanobacteria in lakes. In: The Ecology of Cyanobacteria. Whitton B. A. \& M. Potts (eds.).: 195-231. Kluwer. Dordrecht

STOERMER, E. F., G. EMMERT, M. L. JULIUS \& C. L. SCHELSKE. 1996. Paleolimnological evidence of rapid recent changes in Lake Eire's trophic status. Can. J. Fisheries Aquat. Sci., 53: 1451-1458.

TAYLOR, W. D., J. W. BARKO \& W. F. JAMES. 1988. Contrasting diel patterns of vertical migration in the dinoflagellate Ceratium hirundinella in relation to phosphorus supply in a north temperate reservoir. Can. J. Fisheries Aquat. Sci., 45: 1093-1098.

THORNTON, K. W., B. L: KIMMEL \& F. E. PAYNE. 1990. Reservoir limnology: Ecological perspectives. John Wiley \& Sons, New York. 246 pp.

TRANVIK, L. J., K. G. PORTER \& J. McN. SIEBURTH. 1989 Occurrence of bacterivory in Cryptomonas, a common freshwater phytoplankter. Oecologia, 78: 473-476.

VANNI, M. J. 2002. Nutrient cycling by animals in freshwater ecosystems. Annu. Rev. Ecol. Syst., 33: 341-370.

VENTURA, M., LL. CAMARERO, T. BUCHACA, F. BARTOMEUS, D. LIVINGSTONE \& J. CATALAN. 2001. The main features of seasonal variability in the external forcing and dynamics of a deep mountain lake (Redó, Pyrenees). J. Limnol., 59 (Suppl.1): 97-108.
VICENTE, E. \& M. R. MIRACLE. 1984. Distribution of photosynthetic organisms in a temporal stratified karstic pond near Cuenca, Spain. Verh. Internat. Verein. Limnol., 22: 1704-1710.

VICENTE, E. \& M. R. MIRACLE. 1992. The coastal lagoon Albufera de Valencia: An ecosystem under stress. Limnetica, 8: 87-100.

VICENTE, E., A. CAMACHO \& M. R. RODRIGO. 1993. Morphometry and physico-chemistry of the crenogenic meromictic lake El Tobar (Spain). Verh. Internat. Verein. Limnol., 25: 698-704.

VILA, X., M. DOKULIL, L. J. GARCÍA-GIL, C. A. ABELLÀ, C. M. BORREGO \& L. BAÑERAS. 1996. Composition and distribution of phototrophic bacterioplankton in the deep communities of several central European lakes: the role of light quality. Arch. Hydrobiol. Beih. Ergebn. Limnol., 48: 183-196.

VINCENT, W. F. \& C. R. GOLDMAN. 1980. Evidence for algal heterotrophy in Lake Tahoe, California-Nevada. Limnol. Oceanogr., 25: 89-99.

WALSBY, A. E. 1994. Gas vesicles. Microbiol. Rev., 58: 94-144.

WETZEL, R. G. 2001. Limnology. Academic Press. San Diego, CA. 1006 pp.

WILLIAMSON, C. E., R. W. SANDERS, R. E. MOELLER \& P. L. STUTZMAN. 1996. Utilization of subsurface food resources for zooplankton reproduction: Implications for diel vertical migration theory. Limnol. Oceanogr., 41: 224-233.

WINDER, M., H. R. BUERGI \& P. SPAAK. 2003. Seasonal vertical distribution of phytoplankton and copepod species in a high-mountain lake. Arch. Hydrobiol., 158: 197-213.

WOLIN, J. A. \& E. F. STOERMER. 2005. Response of a Lake Michigan coastal lake to anthropogenic catchment disturbance. J. Paleolimnol., 33: 73-94.

ZVIKAS, A. 2005. Structure of microorganism communities and peculiarities of their activities in gypsum karst lakes of northern Lithuania. Doctoral dissertation, Institute of Botany, Vilnius University, Lithuania. Abstract. 37 pp. 